\title{
Hans Lassen Martensen's Construal of Aesthetics
}

\author{
Curtis L. Thompson \\ Thiel College, Pennsylvania, USA
}

\begin{abstract}
Denmark received a significant contribution in the area of nineteenthcentury idealist aesthetics from Johan Ludvig Heiberg. A younger colleague, Hans Lassen Martensen, learning from Heiberg though operating with an independent spirit, eventually gained his mentor's respect and confidence and became a partner in the cause of championing Hegelian aesthetics during the period from 1834 to 1841 . The task of this essay is to examine Martensen's construals of aesthetics during this time, with the examination culminating in a consideration of Martensen's thoughts on Heiberg's New Poems. The case will be argued that, while those reflections are clearly influenced by thoughts of G.W.F. Hegel and Heiberg, they develop into a construal that is shaped even more so by Martensen's theological commitments.
\end{abstract}

Key words: Martensen, Heiberg, Aesthetics, Lenau, Faust.

\section{Resumen}

Johan Ludvig Heiberg hizo una importante contribución a Dinamarca en el ámbito de la estética idealista del siglo diecinueve. Su colega más joven, Hans Lassen Martensen, siguiendo el ejemplo de Heiberg, aunque operando con un espíritu independiente, en su momento se ganó el respeto y confianza de su mentor, convirtiéndose en su socio en la misión de defender la estética hegeliana durante el periodo entre 1834 y 1841. El propósito del presente ensayo es analizar la interpretación de Martensen sobre la estética de su época; el análisis concluirá con una consideración acerca de los pensamientos de Martensen sobre los Poemas nuevos de Heiberg. Se argumentará que si bien tales reflexiones mostraban la influencia clara de Hegel y Heiberg, en ellas aparece un planteamiento moldeado incluso más por los compromisos teológicos de Martensen.

Palabras clave: Martensen, Heiberg, estética, Lenau, Fausto. 
The philosophical tradition of German Idealism provides the background for reflections on aesthetics of both Heiberg and Martensen. A major development in that tradition was the 1790 publication of Immanuel Kant's Critique of the Power of Judgment. If the Critique of Pure Reason had established limits to knowledge so that the "thing in itself" could not be known, and if the Critique of Practical Reason had reduced the ideas of God, freedom, and immortality of the existential arena to mere postulates that needed to be affirmed so as to bring coherence to the moral endeavor, then the third critique, besides reuniting the bifurcated domains of knowing and doing or fact and value that had resulted from the first two critiques, had a positive, reconciling impact. As Robert Pippin contends, it "generated a much different and far more positive, hopeful, even revolutionary reaction that lasted for many generations afterward, especially in the European tradition that includes and is oriented by the work of Schelling, Schiller, Schlegel, Hegel, Schopenhauer, Nietzsche, Heidegger, Adorno, Benjamin, and many others"; for in this work that would be so influential on aesthetics Kant was defending the claim

that there was a unique mode of buman intelligibility altogether, aesthetic intelligibility, affective and largely sensible but uniquely determinate and not merely a reactive response, and that such a mode of awareness was in some, even if in a quite cognitively unusual and difficult to categorize sense, revelatory in a still deeply important way. That deeply important way involved what was revealed or, more accurately, exemplified about the status of human freedom. ${ }^{1}$

This distinct sort of aesthetic intelligibility came about through the free play of faculties in relation to objects of nature and assumed the form of "a noncognitive but genuine and credible experience (...) of the purposiveness of nature." 2 Nature, then, was not merely disclosing to humans its sensible features, but, since it was generating thought about purposiveness that was relevant to freedom in its moral deliberations, was also disclosing to humans its "supersensible" features, which dimension is essential for understanding

${ }^{1}$ Robert B. Pippin, After the Beautiful: Hegel and the Philosophy of Pictorial Modernism, Chicago: The University of Chicago Press, 2014, p. 10.

${ }^{2}$ Pippin, After the Beautiful, p. 11. 
ourselves as free agents. ${ }^{3}$ For Kant, therefore, the experience of the beautiful or the aesthetic dimension of our existence provided the human with a basis for rendering intelligible and credible her freedom and responsibility: elevating "the aesthetic dimension of human experience" to "a unique aesthetic mode of self-knowledge" meant that life's most important matters could be addressed intelligibly, in fact, "only aesthetically" — and as the fine arts were joined to the beautiful as means for experiencing reality's profundities, beauty and art became central for the human's realization of freedom. ${ }^{4}$ It can be seen that Kant's third critique, through its development of "aesthetic intelligibility," in which concept and intuition were "logically distinct" but "not actually separable in experience," helped to secure the compatibility between our moral task of freedom and our aesthetic appreciation of nature. ${ }^{5}$

The claim of the inseparability of concept and intuition was advanced in interesting ways by Fichte, Schelling, and Hegel, but because of his impact on Heiberg and Martensen during our period of consideration, it is the third of these figures who deserves our attention here. Hegel had delivered lectures on aesthetics in Heidelberg and then four times in Berlin in 182021, 1823, 1826, and 1828-29. Heiberg's famous revelation experience and resulting philosophical conversion to Hegel's philosophy had taken place in the fall of 1824, after his "two-month stay in Berlin in the summer of 1824" when "he had several conversations with Hegel and his followers." 6 Since a version of Hegel's lectures on aesthetics was published during the years 1835 to 1838 only after Hegel's 1830 death, Heiberg likely had no "firsthand familiarity with Hegel's philosophy of art" as Heiberg was working out his aesthetic theories in the 1820s, and apparently his only access to Hegel's lectures on aesthetics was in the form of some borrowed excerpts. ${ }^{7}$ This resulted in some differences on many fine points between the two

${ }^{3}$ Pippin, After the Beautiful, pp. 11-12.

${ }^{4}$ Pippin, After the Beautiful, p. 13.

${ }^{5}$ Pippin, After the Beautiful, pp. 14-15.

${ }^{6}$ Tonny Aagaard Olesen, "Heiberg's Initial Approach: The Prelude to His Critical Breakthrough," in Johan Ludvig Heiberg: Philosopher, Littérateur, Dramaturge, and Political Thinker, ed. by Jon Stewart, Copenhagen: Museum Tusculanum Press / Søren Kierkegaard Research Centre, University of Copenhagen 2008, pp. 211-245, p. 222.

${ }^{7}$ Carl Henrik Koch, "Heiberg's 'Hegelian' Solution to the Free Will Problem," in Johan Ludvig Heiberg: Philosopher, Littérateur, Dramaturge, and Political Thinker, ed. by Jon Stewart, Copenhagen: Museum Tusculanum Press / Søren Kierkegaard Research Centre, University of Copenhagen 2008, p. 6. 
men's aesthetic theories. Yet, on many major points and on the overall spirit of Hegel's philosophy, the creative Danish thinker captured much of what Hegel was about in reflecting on aesthetics.

In Hegel's posthumously published work on aesthetics the dialectical method lies more in the background than in his other philosophical works. Historian of aesthetic theory in the West, Bernard Bosanquet of the British philosophical school of Idealism, offers relevant insights into Hegel's aesthetic. He explains that in the description of the evolution of beauty, with every process of change, that which ceases to exist does so "because its nature is no longer adequate to the claim made upon it by the connected system in which it has its being": "in every causal process, any element which ceases to be, must necessarily be replaced by something more adequate than itself to the requirements of the process as a whole." Important notions in this work are the Idea and the Ideal. "Beauty is the Idea as it shows itself to sense," and the Idea, manifesting itself in forms appearing in life and in consciousness, "is the concrete world-process considered as a systematic unity": while the Idea shows itself to sense in "the beautiful," it also has an identical substance but different form as it, on the one hand, is grasped by thought as "the true," and as it, on the other hand, has to do with the will or desire as "the good." The Idea of the beautiful is grasped more and more fully as one is led through the unfolding progression of the Ideal, which is "the Idea as manifested in the chief historical types or phases of art." ${ }^{10}$ The Idea of beauty is manifested in nature, but then as it is given its fullest nonsensuous expression in human intelligence, it proceeds "as it were to repeat consciously the process by which it was unconsciously embodied in nature, and construct for it itself a more adequate representation equally actual for sense in the second nature of art":

Now the entire subjective aspect of this process, the matter which is imagined in forms capable of representation, constitutes, according to Hegel, the Ideal, that is to say, the Idea so translated into the terms or tendencies of imagination as to be capable of direct or indirect presentation to sense. Concreteness is the bridge to artistic realization. ${ }^{11}$

${ }^{8}$ Bernard Bosanquet, A History of Aesthetic, Cleveland: The World Publishing Company, 1932; $3^{\text {rd }}$ edition, 1961, p. 335.

${ }^{9}$ Bosanquet, $A$ History of Aesthetic, p. 336.

${ }^{10}$ Bosanquet, A History of Aesthetic, p. 337.

${ }^{11}$ Bosanquet, A History of Aesthetic, p. 340. 
The Ideal, for Hegel, is seen to evolve, so that he identifies modes of imaginative capacity that are applicable to given artistic media of artistic expression "within each of the great historical forms or stages of the 'ideal' or art-consciousness," with the three successive phases yielding Hegel's three forms of art of the symbolic, the classical, and the romantic. Bosanquet contends that Hegel's treatment of the Ideal is the greatest single step that has been made in the history of aesthetics, and this was centered in the actual change that the Ideal as the equivalent to the beauty of art had undergone as it passed through the human mind and became charged with something more than the deepest insight could find in nature: this centered in an appreciation of the vital role played by the imagination as applicable to a particular range of artistic production, an appreciation Hegel shared only with Schelling. ${ }^{12}$

Hegel, like Kant before him, maintains "that aesthetic intelligibility is a distinct sensible-affective modality of intelligibility." ${ }^{13}$ And like Kant, Hegel linked artistic sensibility to the human's quest for freedom. Hegel insisted that his treatment of art, as with his treatment of religion and philosophy, be understood in its greatest meaning in relation to the human's grasping of itself in its endeavor to be free. For Hegel, human development at its most profound is about the process of becoming free, and for him "freedom is the highest destiny of the spirit." ${ }^{14}$ If as Pippin suggests, the core of Hegel's narrative is "the realization of freedom," then that is the case for his historical treatment of art no less than it is for his philosophy as a whole; and that is why art historian E. H. Gombrich called Hegel the "father of art history." 15 Unpacking Hegel's view of freedom carries us into what he labels the logic of the inner-outer relation. A person cannot internally understand herself as free apart from experiencing herself through external actions, and artistic expression and production is a form of such actions. Pippin's work has helpfully emphasized the social character of Hegel's theory of freedom,

12 Bosanquet, A History of Aesthetic, pp. 342, 348.

${ }_{13}$ Pippin, After the Beautiful, p. 135.

${ }^{14}$ Hegel's Aesthetics: Lectures on Fine Art, trans. by T. M. Knox, 2 vols. Oxford: Clarendon Press 1975, I:97.

${ }^{15}$ Pippin, After the Beautiful, p. 18. Pippin writes, p. 133: "That common Hegelian narrative is supposed to concern "the realization of freedom," and the role of art in such an enterprise is as a historically sensitive and sensible-affective mode of collective selfknowledge, the collectively available, sensibly-mediated self-knowledge necessary for a free life in common." Self-knowledge comes about through the conflict of interpretation that is called for by such sensible embodiments of self-understanding. 
namely, that beyond affirming my freedom through my subjective awareness in which "I can fully recognize myself in the deeds I bring about, (...) there is another crucial condition that must be fulfilled: those bodily movements count as the deed I intend only if that act description is one recognizable as such in the community in which I express and realize myself." 16 This second aspect of freedom concerns the fundamental nexus of social relations that provides the cultural or communal understanding by which one's deeds become intelligible. In our case that second aspect of freedom will be the social world of Golden Age Denmark. Subjective and objective, inner and outer, work together. Hegel spoke of the speculative relation of these two sides of reality, the inner and the outer. Many of the reflections we will be examining will be informed by this distinction and its overcoming by means of speculation.

\section{II}

In the fall of $1834 \mathrm{H}$. L. Martensen departed on a two-year study trip abroad that furthered his education in many academic areas including aesthetics. His longer stays were in Berlin, Heidelberg, Munich, Vienna, and Paris. The first volume of his autobiography, Af mit Levnet: Meddelelser, is dedicated in large part to documenting experiences he had during his travels. The initial section of this paper was quite abstract in its dealings with concepts relevant to our discussion of aesthetics. I identified a distinctive sort of aesthetic intellectuality, which in combining intuition or sensation and conception, manages to connect communicatively in a relationship quite effectively because images and narratives tend to prevail rather than abstract concepts and because pictures and stories generally have greater appeal with larger groups of people than do philosophical notions. In this section of the essay a concerted effort will be made to utilize portions of Martensen's autobiographical narrative in order to give a more personal touch to the discussion. The hope is that this will provide a personal context for construing Martensen's construal of aesthetics. At times the unrelenting sequence of extensive quotes might become frustrating and maybe a bit irritating for the reader, but I ask you to keep in mind that the intention is to bring us more intimately into Martensen's world in the mid-1830s. Furthermore, most of all this material has not previously appeared in English translation.

${ }^{16}$ Pippin, After the Beautiful, p. 19. 
Martensen writes in his autobiography about finding in the library at Heidelberg a volume of Johannes Tauler's sermons that also included a few sermons by Meister Eckhart:

I knew only single quotations of Eckhart through Hegel and Fr. Bader, but these had given me great desire for a closer acquaintance. I then brought the book home. Both Tauler and Eckhart attracted me to a great extent; I excerpted especially Meister Eckhart, and I resolved deeply to investigate thoroughly the mysticism of the entire Middle Ages. Mysticism, with its at once one-sided and profound talk of a deep humility and spiritual poverty, of a continuous dying from the world and the ego through metamorphosis and rebirth, so that the soul may become united with God; of the imitation of Christ's poor life, of the continuous transformation according to Christ's image, and the soul's submersion into God where it sometimes possibly looks as though the soul was drowned in God as in a limitless ocean, but from which it yet ever ascends since the eternal individuality will not and cannot die-all this grabbed me powerfully, and since the sermons that were offered in the churches did not satisfy me, I sought and found my edification in this. ${ }^{17}$

His studies of mysticism led to the publication of a book on that topic. ${ }^{18}$ They also contributed to the formation of his theological view that would inform his reflections on aesthetics. In Eckhart he appears to have found a speculative soulmate, as his late-in-life communications indicate:

In Eckhart I found in union with the edification the deepest speculative view, religion and speculation as an alliance. The time in which these sermons were published was a time of disintegration in both state and church, and precisely in such a time deeper spirits under the confusion of the world sought to find a time and immovable point, an asylum for freedom, which they found in dying from the world and rising to life in God. Thus, it happened also to me as well, under the confusion of the world that surrounded me, with these spirits to gain freedom in God. I felt myself thrown into a medieval, a monastic frame of mind. ${ }^{19}$

${ }^{17}$ H. L. Martensen, Af mit Levnet. Meddelser [From My Life: Communications], vols. 1-3, Copenhagen 1882-83, I, pp. 126-127.

${ }^{18} \mathrm{H}$. Martensen, Meister Eckart. Et Bidrag til at oplyse Middelalderens Mystik. Copenhagen 1840. (English translation: Meister Eckhart: A Study in Speculative Theology, in Between Hegel and Kierkegaard: Hans L. Martensen's Philosophy of Religion, trans. by Curtis L. Thompson and David J Kangas, Atlanta Scholars Press 1997, pp. 140-243.

${ }^{19}$ Martensen, Af mit Levnet, I, pp. 127. 
Transplanting himself back in time a few centuries was occasioned further by gaining entrance into a work that influenced him greatly and would provide him a perspective for engaging significantly with a friend he would soon make and later with J. L. Heiberg. He writes about that experience:

I had earlier allowed myself to enter into the Middle Ages of Tieck as in a world of adventure. Now it was the deeper tones and higher forms that I encountered, and I was at liberty to deem it very advisable if somebody by a magical wand could allow these to ascend to their old glory. The latter medieval frame of mind was corroborated in me when I simultaneously undertook to study another work from that time, Dante's divina comedia with hell, purgatory and paradise, which I read according to a translation by Streckfuss with notes. This marvelous work, which encircles an entire age, an entire worldview, that of the Middle Ages, became for me a foundation for knowledge of medieval theology, which is completely taken up in the figure of Thomas Aquinas. Concerning the form of the work, I have to agree completely with Schelling's famous remark, that hell is plastic, purgatory picturesque, and paradise musical. Although many believe that paradise is the weakest, I could not quite agree with this since paradise captivated me to such a degree. I listened with the greatest interest to what is said about the condition of salvation, and followed Beatrice with intense interest as she leads the poet from station to station, until she disappears for the venerable old man (Bernard), who leads Dante to contemplation of the Trinity. I can say that this study of mysticism and Dante was the best thing I gained in Heidelberg, and it was, so to say, my secret. As every section in Dante's work closes with a reference to the stars, so it also brought out in me a new knowledge of the stars. When each night in that beautiful summer I made my solitary walk along the Neckar River, I was constantly filled up by mystical feelings with the speculative thoughts and Dante's images. ${ }^{20}$

The reference to the stars, I take it, is to the fact that he encountered the stars on his nightly walk, but his experience of them was now taking place in the context of thinking deep thoughts gained from his encounter with mysticism and Dante, so he was gaining what he took to be in its own way "new knowledge of the stars."

Recollections of his days as a young traveling student explain that it was on his way to Vienna that he fell into speculations on the idea of Faust.

Among some books that were placed in my possession was a new publication on Faust by Lenau. I took and read it. It made on me a pleasant impression

${ }^{20}$ Martensen, Af mit Levnet, I, pp. 127-129. 
and induced me to compare it with Goethe's Faust. However much beauty and genuine poetic artistry I was obliged to find in Lenau, it could yet not occur to me with respect to talent and poetic wherewithal to compare it with that of Goethe. On the other hand, I found to my delight an interpretation of Faust from a completely other point of view from Goethe's, namely, out of a Christian outlook on life, which is the proper, indeed the only proper element in which a Faust can be presented, as indeed the idea of Faust is also born out of Christianity. Goethe's Faust is, as all the poet's productions, a purely individual confession, a pronouncement and presentation of the poet's inner experiences. It is the so-called Sturm und Drang- [Storm and Stress] period in Germany, the unrest, the pressure, which heralded the breaking forth of a new age that at that time stirred in youthful spirits and natures, an age in which Goethe himself and those related to him had here found an expression, their philosophical puzzles, their inner struggle between faith and knowledge, their contempt for scientific philistinism, their search and craving, their longing and unquenched thirst. ${ }^{21}$

The two Fausts, the one by Lenau and the other by Goethe, are going to garner a significant share of Martensen's reflections on aesthetics that we will be investigating. His memoirs find him quickly acknowledging the unquestionable superiority of Goethe's, and yet he does not hesitate to identify what he sees as shortcomings in the tragic play that is the best-known version of the Faust story.

Goethe's Faust is originally only a fragment. By continuation one fragment is merely joined to the next, so that no actual whole is brought about because the presuppositions were lacking. Goethe's Faust is therefore by no means what has often been said, a poem of world historical meaning as Dante's. It is rather not an objective outlook on life that here receives expression, as valid for all of Christendom to which the Faust legend belongs. Goethe belongs only to a single time, and his Faust is only a single writing of a very great individual's confession. However high Goethe's genius must be posited in this work, there is about it, if I am allowed to use the expression, something non-canonical, something artificial, something apocryphal, because it has diverged from its true model, its idea that the poet ought to read in the legend. The outlook on life is pantheistic or half-pantheistic and skeptical, which was suitable for the readers for which he wrote and still goes down well among readers who stand outside the Christian presuppositions and demand only what they call the human. ${ }^{22}$

${ }^{21}$ Martensen, Af mit Levnet, I, pp. 163-164.

${ }^{22}$ Martensen, Af mit Levnet, I, pp. 164-165 
Some of the major features of the theological view-the reality of temptation, the defiant revolt against God that is sin, and the denying of one's true essence-informing the analysis of Faust, and we will see, Dante's divine comedy as well, are set forth in another passage from the autobiography.

His Mephistopheles is a modernized Devil, a principle of negativity, a personification of evil, who is only construed as a negative, but in addition as co-belonging in existence in order to provide opposition, life and commotion. But how different from this is the Christian view. The spirit of darkness, which Christianity teaches us to renounce, is God's and the human's enemy, a creature, who in haughty defiance revolts against the Creator. As Faust gives himself up to him, Faust seeks to deny, reason away [bortraisonnere] his own created essence, his creatureliness, in order to win the independence and selfconstitution of arrogance. Only under these, under the presuppositions of the relations of creation, which with necessity enter into a Christian conception of totality, can an actual Faust be composed. The actual Faust writing, which Christendom will be able to appropriate, still remains to be written and still must be expected. But to the forerunners belongs Lenau's Faust. ${ }^{23}$

Lenau, the pen name of Nicholaus Franz Niembsch Edler von Strehlenau, was a talented young scholar who became a good friend of Martensen. They met in Vienna, in a coffeehouse that was the regular gathering spot for all the young intellectuals in the city who were desiring a mutual exchange of ideas and social interaction. ${ }^{24}$

I made then Lenau's acquaintance in Neuner [Café], where each afternoon I found myself. Despite all the differences that were in our individualities and natural predispositions, it yet turned out that, indeed we opened ourselves more to each other, thus sympathized in that which was the highest, that this acquaintance expanded into a friendship. More and more it developed so that we daily walked together, daily ate together, were incessantly in a mutual, spiritual give and take. I was allowed to know in him a rich and very outstanding spirit, who had prematurely become introduced into the regions of deeper investigation, had prematurely brought life's highest problems under scrutiny. And his human character (Naturel) was pure and noble. How he appraised me can among other things be seen by a letter to Emilie Reinbeck, an older friend, where he in his benevolent jesting calls me a continuous potency, an affront [Hemsko], because I hinder him in writing letters, because I have

\footnotetext{
${ }^{23}$ Martensen, Af mit Levnet, I, pp. 165-166.

${ }^{24}$ Martensen, Af mit Levnet, I, pp. 166-167. Martensen's full account of his relationship with Lenau is given in I, pp. 167-212.
} 
stolen his time, heart and thought (Schurz, Leben Lenaus, I, pp. 324). My conversation he compares with a bath of reason, which holds him captivated. "Already in some weeks," he writes, "I sit in this bath, 4 to 8 times a day."-I for my part can here add, that I also daily sat in a corresponding bath, which he administered to $m .^{25}$

Conversations with Lenau generally took on an aesthetic character, although a political dimension was also present, recalls Martensen nearly a half-century later:

Many of the personalities who gathered here were poets, or hoped to become that, which applied to the majority, for only two or three were that. But with the aesthetic element in the conversation was combined also a political element, which very soon I noticed was a liberal opposition against Metternich and the Metternichian system of government. ${ }^{26}$ Grev Auersperg, Anastasins Grün, who himself was a relative of Metternich, gave in his Spaziergänze in the poem "The Salon" a very sensational description of Metternich. ${ }^{27}$ Metternich goes around in the salon and gives on the most pleasant Maade Cour, while outside of the salon there stands a poor petitioner, namely, the Austrian people, who most humbly ask that he will forgive that it takes freedom to ask whether he will give them freedom. This tone found resonance in Neuner's, where the Metternichian absolutism was considered as oppressing every free movement. Still, such was stated only in subdued tones; for even Neuner's Café was not well regarded by the government, because one had the feeling that here stirred a spirit that could become menacing for the establishment. This can certainly also be said, that the Neunerian Café to no small degree had contributed in Vienna to prepare for the events in $1848 .^{28}$

While political overtones were omnipresent in Neuner's, this was not the case in the Lenau-Martensen relationship.

${ }^{25}$ Martensen, Af mit Levnet, I, pp. 170-71.

${ }^{26}$ Klemens Wenzel Nepomuk Lothar, Prince of Metternich-Winneburg-Beilstein (1773-1859), was an important Austrian statesman who served as a foreign minister (18091821), functioning as one of the organizers of the Congress of Vienna (1814-15), which determined the settlement of Europe after the Napoleonic Wars. He was the Chancellor from 1821 until the liberal revolution of 1848 forced his resignation.

${ }^{27}$ Count Anton Alexander von Auersperg, who used the pen name of Anastasius Grün, was an outspoken critic of the Austrian government. His fame rests largely on his political poetry, two collections entitled Spaziergänge eines Wiener Poeten of 1831 and Schutt of 1835. Martensen here refers to one of his most famous poems, "The Salon," from 1831, in which the Austrian people courteously plead, "May we ask you for the freedom to be free?"

${ }^{28}$ Martensen, Af mit Levnet, I, pp. 168-69. 
The political did not take up any great place in our conversations. I did not have at that time any cultivated political views, while he I dare say had something that could be called a standpoint. He was, namely, coming from liberalism. Now since liberalism has a principal opponent in absolutism, so he hated all absolutism as tyranny and oppression. He hated papism and hierarchy and not least the political absolutism he knew from experience. Yet his liberalism was not so narrow-minded, as I have so often found it in others, who in their criticism of the establishment entangle themselves in multifarious specialties and pettinesses, but which are without ideas and without breadth of view. Lenau's liberalism had an ideal, a universal and cosmopolitan character. $\mathrm{He}$ saluted human rights. The political was in him taken up with a higher reality, and the freedom ideal, for which he was enthused, was after all the human's eternal personality ideal, which was obliged to have a right to unfold itself under the earthly relations. ${ }^{29}$

It is no surprise that theology with a philosophical emphasis was a frequent subject of their dialogue. Martensen refers to it as philosophy of religion, which at that time was a category that had not been used for very many decades. Presented here are some thoughts that we will encounter again.

Our conversation moved especially in a philosophy-of-religion direction. We talked with each other about pantheism, about God's and the human's personality, with this also about Spinoza, Goethe, Hegel, and Fr. Baader, whom he knew not at all, and to whom I first drew his attention. It is well known that he afterwards sought Baader's personal acquaintance, that Baader dedicated to him an installment of his Lectures on Speculative Dogmatics, and that Baader gave him a practical word of wisdom for the road, which Lenau stuck in his hat as a fresh forest green: Die Gescheidten werden immer gescheidter und die Dummen werden immer dummer. [The clever ones are becoming more and more clever and the stupid ones are getting more and more stupid.] We talked likewise about mysticism, about the Middle Ages and the Reformation, about the present age's disorganization and about the necessity of a spiritual rebirth by Christianity. At that time he declared as his conviction that not merely science, but also art and poetry ought to work toward a transformation of the time's spiritual consciousness. Therefore, he very definitely raised objections to aesthetic formalism, the artistic indifferentism, which does not care about the religious-moral substantial truth, but only about the so-called beautiful form. The true poet, just as the true prophet, posits a true consciousness of eternity against the consciousness from the mere spirit of the time and that filled up with the tenets of the false prophets, is obliged to proclaim true views, speak judging and liberating words into his time (...) Niembsch was

${ }^{29}$ Martensen, Af mit Levnet, I, pp. 173-74. 
Catholic, but had a freer conception and recognition of the significance of the Reformation. His recognition of Luther still had its considerable limitations. Often in his conversation he returned to what I have also heard from other Catholics, that both in Luther's personality and work there was something coarse and plebiscite, verging on the vulgar, which made him unqualified for being an apostolic character. I responded that precisely a man as Luther with these coarse flavorings was that which the time then needed. There was need for a man who could strike a bludgeon stroke. ${ }^{30}$

Yes, these two intellectuals also discussed aesthetics, but we can see that those discussions did not take place without a broad consideration of the many arenas of life.

One of the artistic endeavors that gained significance in the relationship was music. Martensen had played the violin since his youth. But we learn that in this area Lenau excelled to an amazing extent.

Lenau captivated not merely by his rich conversation and what he gave as a poet. He captivated also, if one was not devoid of sense, by his exceptional musical gifts by which he opened a new side of his remarkable individuality. First he had masterly played guitar, but this had seemed to him to be too narrow, and he had completely thrown himself into the violin. I have heard many great violin virtuosos, but nobody who in execution, in expression could compare with him. A great virtuoso, who at that time heard him play, exclaimed in wonder and in a sort of shock: "Lord Jesus! What would have you been able to become, if you had made the violin your profession." Lenau himself sometimes thought that he should have chosen neither the violin nor poetry. Often after he played Austrian dances he passed into the most plaintive and touching sounds. But the center of his playing was Beethoven, who for him in music was one and all. He perpetually played long passes of Beethoven, which he could do by heart and continued in private fantasies. $\mathrm{He}$ had written a poem: "Beethoven's Bust," which is found in the second volume of his collected works. When I read this poem, I can still hear the violin passages he played before me. ${ }^{31}$

We are getting a sense for the expansive humanity of Lenau. The fact that these two became soulmates tells us that Martensen himself was also a person of uncommon substance. Music is one area that they ended up having to agree to disagree.

\footnotetext{
${ }^{30}$ Martensen, Af mit Levnet, I, pp. 171-73.

${ }^{31}$ Martensen, Af mit Levnet, I, pp. 178-79.
} 
I talked sometimes with him about Beethoven and Mozart, which latter was my musical ideal. But he would not at all allow Mozart to come up against Beethoven. Mozart is all too jovial, he said. There is in the human breast a font of pains and sufferings, which Mozart has known not at all, but which Beethoven has known and been able to reproduce in sounds. If I emphasized "Don Juan," where not merely jovial sounds, not merely romantic sounds, but also the most serious and deepest sounds from the spirit-world are heard, neither would he grant this validity. "Figaro," he said, is Mozart's proper genre; here he is at home. He added: A requiem Mozart cannot write. One notes the forced, the artificial, the compelled, while it flows in Beethoven. MendelsohnBartholdy he allowed more or less to pass. Yet Mendelsohn could not write an oratorium. His "Paulus," he shall have found very feeble and weak. Even Lenau had an idea for an oratorium: Judas Ischariot, who waited for the right composer. $^{32}$

One last music-related account can be justified for inclusion in our narrative because in it we learn a little about Martensen's good-natured humility about his finitude.

He [Lenau] persuaded me to take up again my shelved violin playing, and was even with me in an instrument maker shop where there created Machini violins. Concerning my own bungling shall here not be told, especially since the whole did not lead to anything, and I still soon had to shelve the violin, my childhood's love, forever. Only one thing will I recollect. One of Lenau's teachers on the violin once said to him: See you, my dear Lord von Niembsch! Everything depends on this, that in a Beethovenian composition on the violin one ought in such a case always to have an abyss by one's side, in order immediately to be able to throw oneself into it, if one plays out of tune. Lenau always met with certainty the high pitch or another high note, which in the Beethovenian compositions required an abrupt, so to say, infinite leap on the violin. I for my part never attempted this, since I obviously foresaw that I would have immediately been obliged to throw myself into the abyss. But apart from this or that individual there was the one, who then became to me important and lay in my heart, in the whole set of people to find the right sound on the violin. Only after hearing Lenau did I believe to have received a concept of what that sound would say. ${ }^{33}$

A complicating factor in the relationship was the matter of a cult, a cult centered about Lenau. Apparently the dashing, vibrant young Austrian poet had a magnetism about him.

${ }^{32}$ Martensen, Af mit Levnet, I, pp. 180.

${ }^{33}$ Martensen, Af mit Levnet, I, pp. 182-83. 
If we turn ourselves to the aesthetic, then there was at that time in Vienna a veritable Lenau-cult or Lenau-worship that was especially shorn up by women. It was mainly his lyrical writings that had gained him this favor. In a certain respect it can seem inexplicable, since the Austrian disposition [Naturel] is far more fitted for a life of enjoyment and optimism than for pessimism. However beautiful Lenau's lyrical poems are, either as seen in the intensity and depth of feelings or in the plastic and graphic images, so that they must be said to belong to the most outstanding in German literature, still everything in his lyrical writing is as enveloped in a sleeve's black mourning band. He is the poet of melancholy and pessimism, and not with little justice has his lyrical poetry been aligned with the shining but black mirror-globes we are accustomed to place in the gardens. ${ }^{34}$ Lenau's poetry reflects the sunlit world with all its objects and forms, which are measured with a wonderful natural confidence, but everything is reflected in his disposition's darkness, is reflected in black, in the black globe. One has called him the German Byron, and among the points of comparison which here could be mentioned, can also be mentioned a certain monotony, for in the poets of melancholy and pessimism everything runs into the same, everything is vanity, every hope is disappointed, so that the ideal cannot be found. However much validity pessimism has for the deepest worldview, we yet need daily to employ a proportional optimism. Particularly it requires the cheerfulness, happiness, enjoyment and variety of the Austrian character [Naturel]. Nevertheless there was for Lenau's melancholic writings a general delight, in order not to say adoration, especially among the ladies. One sees what magic poetry can exercise, how it can even defeat also the natural differences and, what indeed was also the case with Byron, can completely take possession of the dispositions, at least for a time. In Lenau's Faust is struck no doubt other tones, and a higher outlook on life emerges. Also this work exerted a charming effect. His Faust was at that time, since I myself recently have become acquainted with this, in the mouths of all, and many read it again and again..$^{35}$

Lenau was a great poet, so he had definite thoughts about other creative writers of lyric poetry:

I also hardly need to say that we also talked about the poets. Goethe he did not love, at least at that time I lived with him. Schiller to the contrary stood for him as a noble spirit, who yet lacked something very essential. About Heine he expressed that he perhaps was the greatest lyric poet in Germany, but it

${ }^{34}$ Martensen is here apparently referring to a form of gas lighting that was used prior to electricity.

${ }^{35}$ Martensen, Af mit Levnet, I, pp. 169-70. 
was to him inconceivable that one could be an actual genius and yet be so "verliederlicht" as Heine was. ${ }^{36}$

And obviously they talked much about Faust.

It lay in the nature of the relation that in our conversations we often were led back to his Faust. I eventually made the decision to write a treatise on this. I communicated to him piecemeal, as I wrote, and had his full and undivided approval. When I came to him in the morning, I found him either playing the violin or lying in bed. He had the bad habit of often to continue lying in bed until late in the morning. As he often could not come into bed at night, then he could not come out of bed in the morning. Therefore, when I came to him in the morning and found him in bed, he had the stamp of the most advanced melancholy, which I nevertheless managed to drive away, as I sat down on the bed and lectured on the piece of my treatise I brought along. After the reading he rose and exclaimed: Masterful! Matchless, etc., an over-evaluation, which can only be excused with his enthusiastic nature. He absolutely wanted for the treatise to be published, and provided me at once with the most highly regarded publisher, namely, Cotta. Also I was obliged, when the treatise was finished, to do a reading on it for a gathering of the brethren from the Neunerian Café. There was unanimous praise for style and presentation. But no doubt it must be assumed what I also assumed, that the same opposition that is found in the time must also be found in the Neunerian Cafe, the opposition between the Christian and the merely humanistic view, which after all will have nothing to do with Christianity. There was agreement regarding the aesthetic construal of Lenau's Faust, in the admiration of the poet's beauties. I sought to direct consideration to a higher interpretation than the merely aesthetic. But this interpretation no doubt contains the seeds to more profound differences. Of remarks that were expressed, I remember that Bauernseld said: "You allow him to say more, than he has thought."

The autobiography gives us access to Martensen's response to responses that were made to his treatise. And we witness the insistent case that Martensen makes for the distinctiveness of Lenau's Faust over against that of Goethe.

In his valuable autobiographical outline of Lenau, Grev Auersperg, who obviously had great sympathy for a so-called purely human construal and in outlook on life stood on Goethe's side, made the remark that I had attempted to claim back the "genuine Christianness" of Lenau's Faust, but with this

${ }^{36}$ Martensen, Af mit Levnet, I, pp. 173.

${ }^{37}$ Martensen, Af mit Levnet, I, pp. 183-84. 
made me guilty of an anachronism, as I already here am supposed to have anticipated Lenau's later Christian standpoint. According to Auerspreg, not faith but doubt is the inspiring in Lenau's Faust. If it caused trouble, I would here readily divide a country for my interpretation, as in addition I must regret that Auersperg, whom I esteem highly, is no longer among the living. It may yet presumably stand to reason that because Faust is presented as a skeptic, that does not necessarily need to mean that the prevailing outlook on life in the poet is the same. And if there is talk of a Christian outlook on life that shall be displayed in a Faust, I must be permitted to ask whether this can have any other basis than the creation-relation and the construal of evil, of Mephistopheles, grounded in this relation. But precisely this, the relation between the creature and the Creator-in which relation the creature will defy and rebel against the Creator, will reason away its creatureliness in order to be able to compose itself in an absolute independence-is consistently expressed in every case definitely aimed at in Lenau's Faust from first to last. Also may be asked how one shall state the reason for writing a Faust after Goethe, if one does not have other, that is to say, have another Faust and another Mephistopheles than Goethe; does not have another thing to come with after all than the same thing, a humanistic, pantheistic or semi-pantheistic outlook on life, with Christian reminiscences sprinkled into it as in Goethe. To compete with Goethe in a purely aesthetic respect, in poetic power, hardly any younger poets can even dream of doing, and would also after all have no interest in doing. ${ }^{38}$

The treatise on Lenau's Faust was published anonymously in Germany and according to Martensen attracted some attention: "In what I have seen in the enormous Lenau-literature, I think that which deals with Lenau and which over the course of years has accumulated, I have not found in the interpretation of Faust anything other than the merely aesthetic treatment, but the problem, the relation between Lenau's Faust and Goethe's I have nowhere found touched on. The outlook on life seems completely to have lain outside the reviewers' horizon as a kind of adiaphora." ${ }^{39}$ Lenau's close friend reports: "I later published my treatise in Danish in a more detailed adaptation, which was published in Heiberg's Perseus. Among Danish readers, namely, in the circle of the younger scholars, I have reason to believe that it produced some effect. Sibbern wrote a benevolent and weighty notification in Maanedsskrift for Litteratur, in which he completely agreed with the view that the purpose in Goethe is an entirely other one than in Lenau." 40

\footnotetext{
${ }^{38}$ Martensen, Af mit Levnet, I, pp. 185-86.

${ }^{39}$ Martensen, Af mit Levnet, I, p. 186.

${ }^{40}$ Martensen, Af mit Levnet, I, pp. 186-87.
} 
Martensen restates his view that the fundamental idea in Lenau's Faust was its stark difference from that of Goethe. His essay's value depended on its success in executing this thought.

Martensen corresponded with Lenau to some extent after their parting. But after a number of years Lenau's melancholy intensified and from 1842 his mental illness progressed in earnest, so that from 1844 he was maintained under restraint in an asylum until eventually in 1850 he died, as a result of having committed suicide. Martensen devoted many pages of his autobiography to Lenau, not because he was writing Lenau's biography, but because he felt that Lenau's biography was such an intensely important part of his own autobiography that he was writing. ${ }^{41}$ Martensen closes his account of Lenau by noting: "his life and destiny serve to affirm the old golden precept: Life ought not be constructed aesthetically, but ethically." 42

Martensen's study trip concluded with a stay in Paris, and the encounter with the Heibergs, Johan Ludvig and Johanna Louise, dominated that experience. Martensen writes about the initial meeting with the distinguished Danish couple:

I went one day to Heiberg's hotel, around 12:00 o'clock noon, which I expressly emphasize since this visit lasted somewhat longer than usual. I received the best and most friendly reception from them both. It did not take long before Heiberg and I were right in the middle of Hegel's philosophy, which he had introduced into Denmark, and for which he continued to work. I had a fair bit of information about the Hegelian situation in Germany, which interested him. When we discussed his work, On the Significance of Philoso$p h y$, I had expected that he would situate himself near the Hegelian left. This was, however, not the case, for all of his statements went in the direction of the Hegelian right, and he placed Marheineke quite high among the theologians. After this it became easier for me to speak and negotiate my views with him. I also told him something of the view at which I myself had arrived. He listened to it with attentiveness. We even came to touch on some points of dogmatics, and although differences were inevitable, I nevertheless had the opportunity to admire the humanity and elegance with which he argued (...). We continued our exchange of ideas for a long time, as I believe, to mutual interest (...). Time flew, and when it was dinner time, Heiberg invited me to eat dinner with them, which I gladly accepted. We then drove to Palais Royal, where we dined at [the restaurant] Vefour. We ate magnificently and Heiberg did not spare the champagne. At the table the philosophical discussion con-

${ }^{41}$ Martensen, Af mit Levnet, I, p. 194.

${ }^{42}$ Martensen, Af mit Levnet, I, p. 212. 
tinued since we began to discuss Heiberg's work On Human Freedom, which in Copenhagen had exercised an educative effect on several of the young people (..... ${ }^{43}$

The eventful evening finally came to its conclusion.

But suddenly I noticed that it was 12:00 in the evening. It was midnight. Where had the time gone? I began my visit as 12:00 noon, and now it was 12:00 at night. The whole thing was like a vanishing dream, from which the midnight church-bells had awakened me. In a dream, time disappears or passes unnoticed. The conversation had become one; I did not recall a single place where the time made itself noticeable, i.e, where there appeared one of those pauses in which one feels exhausted, and where one must collect oneself in order to find something new. Had such a pause appeared, I would certainly have awakened. But everything happened spontaneously (...). When I returned to my hotel, I learned that my fellow countrymen had wandered out in order to look for me-a task, which was certainly difficult in Paris-because they feared that an accident had befallen me. ${ }^{44}$

This night was the beginning of significant relationships for all three in the group.

III

The investigation of Lenau's Faust will be facilitated by examining its extended Danish version that appeared in Heiberg's Perseus in 1837 under the title of "Observations on The Idea of Faust: With Reference to Lenau's Faust." 45 Two parts comprise the essay. In the first part an attempt is made

${ }^{43}$ Martensen, Af mit Levnet, I, pp. 218-220. The translation is from Jon Stewart, $A$ History of Hegelianism in Golden Age Denmark, Tome I: The Heiberg Period: 1824-1836, Copenhagen: Søren Kierkegaard Research Centre / C.A. Reitzel's Publishers 2007, pp. 544-545.

${ }^{44}$ Martensen, Af mit Levnet, I, pp. 225-226. The translation is again from Stewart, $A$ History of Hegelianism in Golden Age Denmark, Tome I, p 546.

45 "Betragtninger over Ideen af Faust. Med Hensyn paa Lenaus Faust," Perseus, Journal for den speculative Idea, no. 1, 1837, pp. 91-164. The essay was republished in Mindre Skrifter og Taler af Biskop Martensen, Udgivne med en Oversigt over hans Forfattervirksomhed af Julius Martensen, Copenhagen: Gyldendal 1885. My references are to the later republication of this extended Danish version. This review has been discussed in George Pattison, Kierkegaard: The Aesthetic and the Religious, New York: St. Martin's Press, 1992, pp. 21-22, and Kierkegaard, Religion and the nineteenth-Century Culture of Crisis, Cam- 
to offer a more general overview of the significance of the figure of Faust; the second part reviews Lenau's Faust. For my purposes, the essay's first part is more germane to an investigation into Martensen's construal of aesthetics, so the focus here falls onto those more general deliberations.

In this essay Martensen is arguing for the distinctiveness of Lenau's Faust over against that of Goethe, and he actually does not spare criticism of both figures. He begins by broadening the scope even further to include Homer and his Iliad. Even then, though, there is room for a younger poet who desires to consider the tragedy of Faust from a point of view contra Goethe, and to do so with an eye on entering into the terrain of the speculative Idea, which we have seen is at the heart of the big picture utilized for construing meaning of creative works when operating from a Hegelian stance. So his opening paragraph runs as follows:

To write a Faust after Goethe, one will without doubt say, is the same thing as writing an Iliad after Homer, a bold undertaking, which can hardly turn out well. One may be entitled [to do this], as long as the assumption stands firm that the viewpoint from which Goethe has construed the idea of Faust is the only one which can and ought to be chosen; for then it would probably be bold for a younger poet to compare himself with that poetic spiritual giant in magical power of execution. If in the meantime a younger poet with true poetic talent attempts to present Faust from a completely different, indeed opposite, viewpoint from the Goethian, to show us this tragic whole in thought's kingdom in a new light, then the claim is placed on the public until further notice to stop with those general observations on the difficulty of writing an Iliad after Homer, etc. But to enter the far more difficult observation of the speculative Idea, which poetry has endeavored to present. For only from this standpoint of the Idea does it allow itself to determine whether Goethe actually has solved the problem or whether the solution of this still remains. ${ }^{46}$

Construing the story of Faust from the vantage point of the Idea will make for a more satisfying solution to the problem addressed than what Goethe delivered.

bridge: Cambridge University Press 2002, pp. 101-103; Robert Leslie Horn, Positivity and Dialectic: A Study of the Theological Method of Hans Lassen Martensen, Copenhagen: Søren Kierkegaard Research Centre / C. A. Reitzel's Publishers 2007 (Danish Golden Age Studies, vol. 2), pp. 131-133; Jon Stewart, A History of Hegelianism in Golden Age Denmark, Tome II: The Martensen Period: 1837-1842, Copenhagen: Søren Kierkegaard Research Centre / C. A. Reitzel's Publishers 2007, pp. 83-91.

${ }^{46}$ Martensen, "Betragtninger over Ideen af Faust,” p. 27. 
We have learned above that Martensen understands the Faust legend to have originated from the soil of Christianity. The Christian view of the fall into sin and resulting human corruption informs the tragic story. Accompanying this emphasis on human depravity is the related notion of God's judgment together with an apocalyptic mentality that envisions the end as imminent. In such a vision evil is a substantial spiritual reality pointing to the opposition between human self-consciousness and God, with the effects of this opposition intruding into the various spheres or regions of creative activity and the intensity of opposition varying with the particular arena in which it appears. ${ }^{47}$ The fall, evil, and the Devil are part of the Christian landscape, and the opposition between God and the human is not confined to the practical side of life. Its greatest intensity manifests itself in life's theoretical side. The drama of Faust finds its life blood and dénouement in the battle that takes place in intelligence. ${ }^{48}$ Martensen, we will see, regards Protestantism as a form of Christianity that is centered in freedom, and Heiberg too seems to adopt this perspective. Here it is Protestantism that possesses the speculative wherewithal and poetic profundity to accommodate the idea under consideration, namely, the reality of self-conscious freedom that is to be gained or lost. This places the idea of Faust above that of both Prometheus and Don Juan. And here speculative poetry reaches its height as the focus falls not on the objects illuminated by the speculative light but on the speculative light itself..$^{49}$ Revelation can be of a relative sort, in which case it is retained within the confines of subjective spirit. Revelation becomes closer to an absolute sort when it involves human striving to constitute a godless kingdom of thought, for then judgment can be seen in relation to such arrogance and the full disclosure of human spirituality can take place. ${ }^{50}$ The drama manages to raise the matters under consideration to the level of highest importance. Human reflection on ultimacy often leads to thought of the end and judgment and that is the case here.

Not all thinking about the end and judgment assumes an apocalyptic form. Anticipated here, though, is the Day of Judgment as identified with the end but as also functioning efficaciously for historical periods preceding the end..$^{51}$ The stages of this special type of poetry are identified. The

\footnotetext{
${ }^{47}$ Martensen, "Betragtninger over Ideen af Faust," pp. 28-29.

${ }^{48}$ Martensen, "Betragtninger over Ideen af Faust," p. 30.

${ }^{49}$ Martensen, "Betragtninger over Ideen af Faust," pp. 29-30

${ }^{50}$ Martensen, "Betragtninger over Ideen af Faust," pp. 30-31.

${ }^{51}$ Martensen, "Betragtninger over Ideen af Faust," pp. 31-32.
} 
first is that found in the last book of the Bible, the apocalyptic document of the Revelation of John. In this stage poetry is still presented in the form of religion. As this Revelation appears within the context of Christianity, an implicit judgment occurs in relation to what is taken to be the two major finite forms of religion, Paganism and Judaism..$^{52}$ Martensen underscores how in this first stage poetry is serving religion to such an extent that talk of a poetry that is in some sense artistic must still be precluded. Poetry gives rise to the beginnings of reflection, but it cannot free itself from the infinite content of the Idea presented symbolically that is monopolized by the predominating religious interest. ${ }^{53}$

History enters the scene as the object world comes into focus by Christianity. Poetry gives shape to art with religion as its content. Medieval Catholicism, stage two of this type of poetry, develops into a religion of art that reaches its height with apocalyptic poetry but now underscoring judgment of a variegated world whose circumference lies within Christianity. ${ }^{54}$ Awareness of dialectical movement in the world has allowed human consciousness to deepen as the complexified outer complexifies the inner. As religion becomes the subject-matter of consciousness, so too does the artistic selfconsciousness assume form and give art's representations greater specificity and beauty. Religion and art thus merge and poetry's highest form has progressed to the height of its second developmental stage in its magnificent exemplar of Dante's Divine Comedy, with its three great spiritual regions. Disclosed in this artwork is Catholicism's best. ${ }^{55}$

The extensive breadth of the poetic image-world needs to be traced back to the intensive where the poetic self-consciousness is penetrated with contemplation of the infinite. The center of this intensive consciousness is freedom, for hell, purgatory and paradise are forms of revelation of the universal kingdom of freedom and self-conscious thought. ${ }^{56}$ At this point, the highest standpoint has not yet been reached. That is because poetry has not yet turned its attention to the source of the creative thinking that has been appearing. Thus far, its reach has not extended beyond the full account of external reality into the internal font of the outer in all its fullness.

52 Martensen, "Betragtninger over Ideen af Faust,” pp. 32-33. The stereotypical categories, of course, such as we encounter here are no longer regarded as accurate or satisfying as types of these two rich religious traditions.

${ }^{53}$ Martensen, "Betragtninger over Ideen af Faust," p. 33.

${ }^{54}$ Martensen, "Betragtninger over Ideen af Faust," pp. 33-34.

${ }^{55}$ Martensen, "Betragtninger over Ideen af Faust," pp. 34-35.

${ }^{56}$ Martensen, "Betragtninger over Ideen af Faust," pp. 35-36. 
Required is to push matters back to the source, which is the imagination or fancy. In Kant's 1887 first critique, Critique of Pure Reason, he had distinguished between the transcendental analytic, which broke the external world down into its parts, and the transcendental dialectic, which brought the parts back together into a whole; but before treating these two, he advanced his transcendental aesthetic, in which he claimed that consciousness of sensation or perception involved a priori intuitions of space and time in and through which sense-perceptions were experienced. Martensen advises that Dante's spheres of hell, purgatory and paradise are to be regarded as fundamental intuitions of the imagination in and through which objects are to be construed; and he suggests that this should be seen as being analogous to Kant's intuitions of space and time. For Martensen, it is the imagination and the freedom being served by it that here becomes the privileged content for the highest observations. ${ }^{57}$ Faust thus represents a progression beyond both John's Revelation and Dante's narrative, for the all-encompassing reality of human freedom has come center stage. Stage three of poetic development has been reached. Despair and doubt are two themes mentioned that will later receive further attention and then later still become major categories for another major Danish religious thinker. Thought in its free selfdetermination struggles with how it is going to compose itself in relation to knowledge. The ultimate destiny of the tragic hero is being determined.58

Ideality is the world of possibility rendered relevant as a goal for a region of human endeavor. Here we are informed that within Protestantism the Divine Comedy comes to be understood as exhibiting an ideal that needs to be relativized, stripped of its absolutizing standpoint, and the Faust account gives expression to such judgment. ${ }^{59}$ The poetic form of Faust transcends both that of the Christian biblical text and of Dante's medieval text. In Faust, mythology is reduced from multiple external figures to the two major players-Mephistopheles and Faust-who enact not an extensive drama centered on external characters spectacularly presented but an intensive drama centered on a relationship in which thought is highlighted. ${ }^{60}$ Those with whom one associates can influence who one becomes. It becomes clear

\footnotetext{
${ }^{57}$ Martensen, "Betragtninger over Ideen af Faust," pp. 36-37.

${ }^{58}$ Martensen, "Betragtninger over Ideen af Faust," pp. 37-38.

${ }^{59}$ Martensen, "Betragtninger over Ideen af Faust," pp. 38-39.

${ }^{60}$ Martensen, "Betragtninger over Ideen af Faust," pp. 39-40.
} 
that the guides Beatrice and Mephistopheles bestow wildly different experiences on those they are guiding, Dante and Faust respectively. ${ }^{61}$

Doubt is the form of the negative present in dialectical thinking that can become the speculative. Such negativity is present as well in understanding dogmas, and Christianity's truth is able to solve the problem of various dogmatic claims being cast asunder into irresolvable oppositions by reflexion. ${ }^{62}$ Freedom needs to contend with itself so that a higher form of freedom can emerge. Doubt, we learn, is an ingredient in movement toward the truth, as is temptation, which is comparable in the practical arena to what doubt is in the theoretical. In addition to temptation [Fristelsen], we also encounter here the verb reduplicated [fordobblet], both of which will become important notions for a Danish contemporary. ${ }^{63}$

With the big moment of decision at hand, Faust in his freedom determines his future. The reference to Pan is to the Greek God of religion and mythology who had goat features, was associated with fertility and new growths of springs, and became significant in the Romantic movement. ${ }^{64}$ The monumental significance Martensen attributes to the development of Protestantism becomes apparent in the next portion of his narrative. It is this form of religion-generated out of the causal flow dispersed by Luther's potent manifestation of the principle of subjectivity in his "Here I stand, I can do no other" claim when confronted by the authorities-that allowed the negative to be given its due on the world's stage. The independent thinking spirit became the basis for freedom finding its way into all of life's spheres, from the political to the artistic with Faust being the latter's best model. ${ }^{65}$

We next are given a welcomed qualification. Certain points of view and perspectives, such as the particular philosophical standpoints and particular religions such as Judaism, have been presented in a pretty negative light. Here we receive word that besides the status a given reality is designated within the dialectical consideration at hand, it also has a more substantial side to it that gets lost in apocalyptic poetry's considerations. There is no backing off from the black-and-white judgments being offered about nonChristian religions, but this acknowledgement softens the rhetoric to some

${ }^{61}$ Martensen, “Betragtninger over Ideen af Faust,” p. 40.

${ }^{62}$ Martensen, "Betragtninger over Ideen af Faust," pp. 40-41.

${ }^{63}$ Martensen, "Betragtninger over Ideen af Faust," pp. 41-42.

${ }^{64}$ Martensen, "Betragtninger over Ideen af Faust," pp. 42-43.

${ }^{65}$ Martensen, "Betragtninger over Ideen af Faust," pp. 43-44. 
extent and breathes a little fresh air into what seems to be a quite closed system. ${ }^{66}$

In discussing the cultural form of science, the development of freedom in the realm of science gone astray is compared to the history of the temptation of Christ. Science loses faith in thought as it moves away from idealism to empiricism. Idea's truth comes to appear as a Fata morgana, a term Heiberg will use in an 1838 play that we will examine in the essay's next section. As the human spirit gives up on the Idea, it adopts a positivist, foundationalist form of science. A famulus is an assistant or servant, especially working with a scholar, and Wagner is referred to as Faust's assistant and also the brother of Gretchen, his love. ${ }^{67}$ Taking too seriously the scholarly efforts involved in the physical sciences and in making sense of history do not bring the highest satisfaction. In fact, the fruitless effort to turn stone to bread is characterized as a bad [slette] one, a designation of inadequacy that we will delve into in the essay's section on Heiberg's New Poems. ${ }^{68}$ The subjective idealist Johann Gottlieb Fichte (1762-1814) comes to mind in a description Martensen offers, and arrogance is linked to the ego and its absolutizing of itself in defiance of faith. ${ }^{69}$

Martensen introduces his central thought that the human being determines the nature of who and what she is going to be in the decision she makes in relation to the Creator. The decision to adopt the faith stance and to grant one's dependence upon God means that one sort of person is coming into being. Unwillingness to make such a decision means that another sort of person is coming into being. The former is the stance of an autonomous person acknowledging the theonomous situation she is in; the latter is that of using one's autonomy to deny the theonomous situation. That theme of autonomy in its relation to theonomy was the focus of the dissertation Martensen was writing at this time on the Autonomy of Human Self-Consciousness in Modern Theology.$^{70}$ Here is how the matter gets stated in this context:

${ }^{66}$ Martensen, "Betragtninger over Ideen af Faust," pp. 44-45.

${ }^{67}$ Martensen, "Betragtninger over Ideen af Faust," pp. 45-46.

${ }^{68}$ Martensen, "Betragtninger over Ideen af Faust," p. 46.

${ }^{69}$ Martensen, "Betragtninger over Ideen af Faust," pp. 46-47.

70 Johannes Martensen, De autonomia conscientiae sui bumane, in theologiam dogmaticam nostril temporis introducta. Copenhagen. Danish translation: Den menneskelige Selvbevidstheds Autonomie, trans. by L.V. Petersen, Copenhagen: 1841. (English translation: The Autonomy of Human Self-Consciousness in Modern Dogmatic Theology in Between Hegel and Kierkegaard: Hans L. Martensen's Philosophy of Religion, trans. by Curtis L. 
As then Faust under the whole process must relate himself negatively against Christian dogma (...) so doubt, as it experiences the different stages of its negative process, must finally move towards the point that seems to be the central point in the worldview it is on the verge of demolishing, the point in which all religious-ethical concepts, the concepts of good and evil, faith and knowledge, mystery and revelation, have their final root, life's fundamental mystery from which all wonders originate, namely, the idea of the Creator in its relation to the creation. Here lies the proper stumbling block of all irreligious systems; for in this dogma is given proof of faith's necessity for the created spirit. As long as this dogma stands firm, things fare only badly with the human spirit's absolute independence. Here it is realized that that which impedes the spirit's tantalizing striving for an unlimited knowledge is not a mere appearance, but its own innermost essence, its created nature, its creatureliness. For the conscience, the created spirit's character indelebilis, contains for the finite spirit inalienable certainty, that as God's creature it has God as its presupposition, and just as little can it itself substantiate its thought as its being. ${ }^{71}$

The defiant one rebels against God, which in Martensen's view is at the same time rebelling against the human conscience. Such forceful exertion of energy ends in despair. ${ }^{72}$

Paradise in Faust cannot be described because that is possible only on Christian grounds and therefore would require a transcending of the bounds of the work, unlike in Dante's and John's writings where that presupposition is met and makes possible descriptions of Paradise. ${ }^{73}$ Martensen sings the praise of Protestantism, of its independently striving art, and of Goethe as that art's greatest representative. The meaning and value of secular life is embraced and the reality of the world is taken seriously. ${ }^{74}$ But the absolute has not been arrived at by art. Art's secularity is being affirmed, but when it ascends to a higher level it shall again be reunited with religion. Not that secular art forms will vanish, but in select works and with select viewers transfigured art of great glory will be experienced. Lenau's writing on Faust is apparently being construed as one of those works uniting art and religion at a higher level. ${ }^{75}$ In Goethe's Faust it is the pantheistic perspective that

Thompson and David J. Kangas, Atlanta: Scholars Press 1997, pp. 73-147.)

${ }^{71}$ Martensen, "Betragtninger over Ideen af Faust," pp. 47-48.

${ }^{72}$ Martensen, "Betragtninger over Ideen af Faust," pp. 48-49.

${ }^{73}$ Martensen, "Betragtninger over Ideen af Faust," pp. 49-50.

${ }^{74}$ Martensen, "Betragtninger over Ideen af Faust," pp. 50-51.

${ }^{75}$ Martensen, "Betragtninger over Ideen af Faust," p. 51 
informs it, although this perspective falls short of a complete worldview because it lacks a center. The opposition we are given, therefore, is nebulous and takes the shape less as an appearance, spectacle, or dream and more as a shadow of these. And evil is embodied more as a principle of negativity than as a personal defiance. ${ }^{76}$

Martensen concludes his extended general treatment of Faust by reiterating his main point: that Lenau's Faust differs from that of Goethe and in fact surpasses the master's in its clear articulation of the central opposition. The full construal of the work would need to be an aesthetic one, but the theological construal cannot be omitted because religion no less than art is a dimension of the work. ${ }^{77}$

Martensen then proceeds to a discussion of Lenau's epic-dramatic writing, which he concludes with the following statement:

I have now attempted to develop the thoughts that are contained in this poem. How far this is from satisfying the requirements of a Faust, which formerly was developed by the concept of apocalyptic poetry, is all too conspicuous to be in need of any further development. Without speaking of the poetic style and tone in which this poem is held, so lies the essential lack revealed in the fact that the poet through the whole presentation has allowed us to see all too little of the theoretical world in which Faust belongs. Thereby his work ends up lacking an essential substantiality. The genuine poetic presentation of the Christian myth of Faust, the poem's Day of Judgment over philosophy, must therefore still be awaited. This will only be able to be introduced when the desire for that higher union of art and religion emerges more clearly in the consciousness of the age; when the Protestant poet, whose gaze not only turns towards nature and history, but involuntarily is drawn towards the intellectual world itself, fully grasps the meaning of this direction of his genius; when, with a clear self-consciousness, he feels his prophetic call, his art's universality. For with the writing of Faust it is valid in a higher sense than usual that in the poetic creation not only power is challenged, but also wisdom. ${ }^{78}$

Just who might be that awaited Protestant poet who is going to produce such a genuine poetic presentation of the Christian myth of Faust? The one who happily authorized the publishing of Martensen's piece on Faust in his new journal, Perseus, might be a good candidate.

\footnotetext{
${ }^{76}$ Martensen, "Betragtninger over Ideen af Faust," pp. 51-52.

${ }_{77}$ Martensen, "Betragtninger over Ideen af Faust," pp. 53-54.

${ }^{78}$ Martensen, "Betragtninger over Ideen af Faust," pp. 87-88.
} 
IV

Prior to Martensen's study trip abroad and his publishing of the pieces on Lenau, he was initiated into apocalyptic thinking when he wrote a critical review of a book on the Revelation of John. This review, which took a stand against author E. G Kolthoff's claim for the Johannine authorship of Revelation, came out in the summer of $1834 .{ }^{79}$ Relying on J. G. Herder's work on Hebrew poetry, Martensen makes the case against a narrowly rationalistic biblical interpretation as not having made adequate use of the Idea in construing texts. Of course biblical texts must be interpreted with an eye on their historical context, but the events of history must be construed in relation to the unfolding activity of God's developing kingdom; from Herder can be learned the importance of recognizing the Apocalypse as a vibrant and symbolic poetic writing whose symbolism needs to be interpreted through a speculative lens that allows the religious viewpoint of the symbols to be ascertained. ${ }^{80}$ This provocative book is not to be taken literally, and yet when looked at in the mirror of the Christian Idea, one can see reflected the contestatory spiritual forces that create a crisis in every historical period: the apocalyptic seer has envisioned the essential meaning of the church in relation to the contentious advance of history that is always at hand: the Revelation's symbols, therefore, are relevant for guiding the poetic deliberations of seers inscribing their significance in new symbols for new contemporary contexts. ${ }^{81}$ Martensen contends that Protestant biblical construing cannot be appropriately carried out without an appropriation of the faith that brings the realities of faith to life within the interpreter, so that within her subjective personal existence there is a basis for fulfilling the demand that the individual must possess the conviction of the biblical canon's authority at first hand. ${ }^{82}$ In other words, there are no Christians at second hand. Thus, faithful higher criticism cannot bypass human freedom.

${ }^{79}$ H. Martensen, "E. G. Kolthoff, Apocalyps Joanni Apostolo Vindicata," in Maanedsskrift for Litteratur, vol. 12, 1834, pp. 1-31. See the helpful discussion of this review by Robert Leslie Horn, Positivity and Dialectic, pp. 56-60. See also my brief treatment of the article, Curtis L. Thompson, Following the Cultured Public's Chosen One: Why Martensen Mattered to Kierkegaard, Copenhagen: Museum Tusculanum Press / Søren Kierkegaard Research Center 2008 (Danish Golden Age Studies, vol. 4), pp. 6-9.

${ }^{80}$ Horn, Positivity and Dialectic, p. 56.

${ }^{81}$ Horn, Positivity and Dialectic, p. 57.

${ }^{82}$ Martensen, “E. G. Kolthoff, Apocalyps Joanni Vindicata," p. 21. 
Martensen's construing of art had here made a beginning. This early article in biblical interpretation represented a solid start on construing the meaning of literature. A handle has been gained on this important apocalyptic piece of literature, an approach to discerning figurative meaning of symbolism had been identified, the value of the Idea as providing the background for construing historical events had been realized, the centrality of freedom within the person doing the construing had been affirmed, and the need to see the intimate link between artistic poetry and religious vision had been acknowledged. These thoughts were maybe preliminary, but they provided a foundation for engaging in more refined thinking while on his study trip and upon his arrival back home.

Not long after returning to Denmark, Martensen wrote a review article of Heiberg's Introductory Lecture to the Logic Course that was published in Maanedsskrift for Literatur in January, $1837 .{ }^{83}$ Heiberg likely regarded this as a sign of their friendship. Not long thereafter the Danish version of Martensen's Faust essay, whose general discussion of Faust we have closely scrutinized, appeared in the first volume of Heiberg's new project, Perseus: Journal for the Speculative Idea. The Heiberg-Martensen collaboration seems to have been on a roll and continued with Martensen's 1838 publication of a review of Heiberg's play Fata Morgana in 1838. Julius Martensen explains that this article offers general comments on the task of the poet and the place of the theater in a period of history dominated by philosophical questions; then it refers to Heiberg's attempt to produce a new dramatic genre of art with the two adventure comedies, "Alferne" and "Fata Morgana," with the latter poetic work being made an object of a detailed consideration. ${ }^{84}$

${ }^{83}$ Martensen, "Indledningsforedrag til det I November 1834 begyndte logiske Cursus paa den kongelige militaire Høiskole. Af J. L. Heiberg, Lærer I Logik og Æssthetik ved den kgl. Militaire Høiskole," in Maanedsskrift for Litteratur, vol. 16, 1936, pp. 515-528. English translation: "Review of the Introductory Lecture to the Logic Course," trans. by Jon Stewart, in Heiberg's Introductory Lecture to the Logic Course and Other Texts, trans. by Jon Stewart, Copenhagen: C. A. Reitzel / Søren Kierkegaard Research Centre 2007, pp. 73-86.

${ }^{84}$ Julius Martensen, Mindre Skrifter og Taler af Biskop Martensen, p 3. Heiberg's Fata Morgana and Martensen's review of it are discussed in George Pattison, Kierkegaard: The Aesthetic and the Religious, pp. 18-23; George Pattison, Kierkegaard, Religion and the Nineteenth-Century Crisis of Culture, pp. 103-107; K. Brian Soderquist, The Isolated Self: Truth and Untruth in Søren Kierkegaard's On the Concept of Irony, Copenhagen: Søren Kierkegaard Research Centre / C. A. Reitzel 2007 (Danish Golden Age Studies, vol. 1), pp. 181-185, 198, 200; 23, Horn, Positivity and Dialectic, pp. 130-139; Jon Stewart, A History of Hegelianism in Golden Age Denmark, Tome I: The Martensen Period 1837-1842, pp. 137160; and Jon Stewart, The Cultural Crisis of the Danish Golden Age: Heiberg, Martensen 
Alferne was a box office success, but with all its complicated thematic dynamics Fata Morgana was a major theatrical and financial disaster. Jon Stewart argues that "Heiberg's friend Hans Lassen Martensen provided Heiberg with the inspiration for the piece [Fata Morgana]." ${ }^{55}$ A sense of responsibility and guilt might have been one of the reasons Martensen's review essay praised the work as an example of apocalyptic poetry and expanded on his understanding of this genre of dramatic writing. Here Martensen "lauds Heiberg as the creator, in Fata Morgana, of a new literary form in which the contrast between the ideal world, as such suprahistorical and supernatural, the archetype for the actual, comes into conflict with an actual world, which wishes to maintain its own independence. The comic form which results from this conflict is fantasy, another sub-form of the genus (...) speculative poetry." 86

Jon Stewart provides a summary of the complex plot, which involves a prince, Clotaldo, raised as a fisherman's son, who falls in love with Margarita, the daughter of a Duke. The poem presents the difficulties of these two becoming united in love, with Morgana's designed actions attempting to destroy Clotaldo, about whom it has been prophesied that he will deprive the fairy of her illusory powers; in the end, Clotaldo and Margarita get together. ${ }^{87}$ In his explanatory notes to this work, Heiberg remarks that its inspiration came from another play that included a minor role by a fairy Morgana. "Fata morgana" designates a meteorological phenomenon like a mirage, which is common along the coasts of Sicily. The locals attribute this natural phenomenon to the work of [a] fairy with the same name. Heiberg seizes on this as the motif for the philosophical question surrounding appearances and illusions." ${ }^{88}$ Fata Morgana uses her powers to keep humans in the illusion that what appears to them, the phenomena, do not contain in themselves the truth, so for truth they must go beyond what appears.

Informing this play is the debate within German Idealism between Kant and Hegel over the matter of whether the "thing-in-itself" can be known. To this question Kant answers "no," and Hegel answers “yes.” Kant's philosophy leaves us with a dualism in which we can only access the phenomenon, but the noumenon lying behind the phenomenon or the "thing-in-itself"

and Kierkegaard, Copenhagen: Museum Tusculanum Press / Søren Kierkegaard Research Centre 2015, pp. 97-116.

${ }^{85}$ Jon Stewart, The Cultural Crisis of the Danish Golden Age, p. 100.

${ }^{86}$ Horn, Positivity and Dialectic, p. 130.

${ }^{87}$ Stewart, A History of Hegelianism in Golden Age Denmark, Tome I, pp. 140-142.

${ }^{88}$ Stewart, A History of Hegelianism in Golden Age Denmark, Tome I, p. 140. 
is inaccessible to human knowing (until the third critique with its combining of concept and intuition or sensation into a distinctive sort of aesthetic intelligibility makes possible a unification of the two domains). Hegel, on the other hand, maintained that there is no final division between what appears and its essence, and that by dialectically and speculatively grasping the Idea, one is grasping the universal essence as it envelops the concrete phenomenon or appearance. For Hegel, the Idea unites the Concept (the universal) and the empirical (the concrete). Grasping the Idea, in Hegel's vision of reality, is construing the concrete universal in which appearance and essence are united. ${ }^{89}$ Hegel, we could say, incorporated into his basic philosophical viewpoint a way in which concept and intuitive perception could be united-in the rational, speculative following of the dialectical progression of the Concept-that Kant could not accomplish apart from producing his third critique.

Fata Morgana, created upon request for the birthday celebration of King Frederik VI, as reviewed by Martensen, is an indication of Heiberg's development as a playwright. He has learned, suggests Horn, that Fata Morgana's hold on human beings lies in their status as creatures of spirit who strive for the ideal, and "this is no objective fate but human freedom's own artifact. The sole escape from the illusions of the fairy queen is in human freedom's capacity to make itself 'a phenomenon of the Idea.' "90 We had noted above in this essay's first section, that reason included not just the subjective dimension, but the objective as well, in that it must find its corroboration within the mindset at play in the social, public sphere. As with a genuine divine revelation that is not complete until the divine giving has been reciprocated by a human reception, so too a genuine work of art is not complete until it has been appropriated by the public. In relation to Fata Morgana, the public is the "cultured" folks who give their support to the theater. Martensen makes the point that the widespread Danish apathy for its theater cannot be dismissed by underscoring the present age's lack of a sense for poetry. Hegelian aesthetics understands poetry as directing "reality back to its ideal source," so that poetry out of sync with the present reality cannot stir the public: Martensen is convinced that if the poet pres-

${ }^{89}$ See the fuller discussion by Stewart of an allegorical construal of Fata Morgana concerning "Hegel's analysis of the nature of appearances and his doctrine of the immanence of thought." Stewart, A History of Hegelianism in Golden Age Denmark, Tome II, pp. 142-147.

${ }^{90}$ Horn, Positivity and Dialectic, p. 134. 
ents to the public its own poetic ideal, that public will be stirred. ${ }^{91}$ This is the value of the masterpiece:

What gives the individual masterpiece its value is that it is a perfect representation of the poetic ideal. Now this poetic ideal is eternal, but nonetheless it is subjected to temporal development, and as long the human race finds itself in history $(\ldots)$ the ideal at every historical point of development will take on a new form which is qualitatively different from the foregoing. So long as the idea which dominates the artistic strivings of an age, as the eternal archetype working to be realized in the entire manifold of different forms, is acknowledged as the Absolute, so long also will the works which are its perfect representation be absolutely satisfying. But if a higher principle enters into consciousness, then this goes beyond the earlier ideal, which is relativized, a fate which the works in which it is realized also suffer, for they can stand no higher than their own ideal. What was before the object of a total enthusiasm must now let itself be satisfied with a relative recognition; what before was totally present now belongs to what has passed. ${ }^{92}$

Arriving at a new ideal is going to demand a change in the poetic subject, who must develop a new eye. Martensen believes that Heiberg's poetry is not of the peripheral but rather of the centered variety and that it is capable of prompting people out of their complacency with the status quo:

Speculative poetry can be defined as a poetry of the center-in contrast to peripheral poetry which holds us enclosed within particular circles in life where it is as if the light of the Idea only shines through the cracks. Speculative poetry is light and ethereal by nature, breaks down every barrier which obscures a view of the infinite (...). Speculative poetry (...) takes the form of a harmonious illuminating light which transfigures life's darkness. ${ }^{93}$

If Romanticism's poetry was in many instances marked by formlessness as it became intoxicated with the immediacy of its enjoyment of the infinite, the opposite emphasis on form was stressed by those in Goethe's school. Speculative poetry of the Heibergian variety unites these divergent strands:

On the contrary, no one in his right mind will think it a fantastic or superficial notion when we argue that the new evolution of poetry which is at hand will

${ }^{91}$ Martensen, "Fata Morgana," Maanedsskrift for Litteratur, vol. 19, 1838, p. 361. See Horn, Positivity and Dialectic, p. 135.

${ }^{92}$ Martensen, "Fata Morgana," p. 365, as quoted in Horn, Positivity and Dialectic, p. 136.

${ }^{93}$ Martensen, "Fata Morgana," p. 367. The translation is by Soderquist, The Isolated Self, p. 181. 
present the clear, organic forms which portray the life of our consciousness sub specie aeterni. This position is not pulled out of the air, because poetry cannot be an exception to the rule which characterized the whole spiritual life, at every point to develop itself in continuity with the foregoing. But all the preconditions, all the moments, through which speculative poetry can mediate itself are given; namely they represent the two universal artistic tendencies which our age has seen-Romanticism with its striving for the infinite, and Goethe's plastic principle - the basic elements which it behooves poetry to mediate. The poetic genius needs only to draw together again the divergent strands into a higher form. ${ }^{94}$

The insistent claim is made that speculative poetry is not allegory, but rather symbolism; and when symbolism is properly understood, then "it can be for us what mythology was for earlier peoples." 95

In this context Martensen also places comedy above tragedy, following Hegel's view presented in the publication of his Aesthetics: tragedy transpires within an ethical consciousness, negotiating demands of morality, and the requirements of worldly affairs without questioning the validity of the norms at play; comedy, on the other hand, operates from a metaethical, speculative consciousness, with this higher standpoint relativizing the concerns and struggles of the ethical consciousness, giving the worldly a quality of non-being. ${ }^{96}$ Unlike tragedy, comedy allows a perspective to be taken that pits essence over against phenomenon, and with this distinction comes a leverage that can activate a "transfiguration of life," insofar as Martensen claims that recognizing the world's vanity is to hold "that the tension between essence and phenomenon within comedy takes the form of a conflict between a subject who understand 'the finite world as erroneous, and understands itself as the only true actuality.' "97 Martensen continues the discussion of comedy by noting that it has within it two major movements, irony and humor ${ }^{98}$, and we will encounter this distinction as well in his review of Heiberg's New Poems to which culminating point of the essay we must at this point finally turn. 137-138.

${ }^{94}$ Martensen, "Fata Morgana," p. 371, and cited in Horn, Positivity and Dialectic, pp.

${ }^{95}$ Martensen, "Fata morgana," p. 371. See Horn, Positivity and Dialectic, p. 138.

${ }^{96}$ Martensen, "Fata Morgana," pp. 377-378. See Soderquist, The Isolated Self, pp. 182-183.

${ }^{97}$ Soderquist, The Isolated Self, p. 183. The quote within the quote is to Martensen's "Fata Morgana," pp. 378-379.

${ }^{98}$ Martensen, "Fata Morgana," pp. 379-381. See also Soderquist, The Isolated Self, pp. 184-185. 
Two Martensen works were published between the 1838 Heiberg review just discussed and the next Heiberg review published in 1841. They were the book on mysticism and the contribution to the debate between rationalism and supernaturalism. ${ }^{99}$

J. L. Heiberg's New Poems were published in December 1840, and one month later Martensen's review of these four philosophical poems appeared in three consecutive days in Fxdrelandet, the newspaper of academic liberalism. ${ }^{100}$ Martensen states in this review that he intends to confine himself to the universal or philosophical or ethical side of Heiberg's poems rather than to write an exhaustive aesthetic criticism. He sees these poems as having arisen under the inspiration of that spirit of modernity which wants to emancipate time from the inner emptiness that has already begun to be experienced. Even though the fully developed richness of the emancipation of time lies in the future, it can be said that Heiberg's poems bear an unmistakable testimony to the actual presence of a poetic breakthrough of

${ }^{99}$ H. Martensen, "Rationalisme, Supranaturalisme og principium exclusi medii I Anledning afh. H. Biskop Mynsters afhandling herom I dette Tidsskrifts forrige Hefte" ["Rationalism and Supernaturalism and the principium eclusi medii. (In Reference to His Right Reverend Bishop Mynster's Treatise on this Subject in the Previous Number of this Journal)"], in Tidsskrift for Litteratur og Kritik, vol. I, 1839, pp. 456-473, and Mester Eckart. Et Bidrag til at oplyse Middelalderens Mystik, Copenhagen 1840. (English translation: Meister Eckhart: A Study in Speculative Theology in Between Hegel and Kierkegaard: Hans L. Martensen's Philosopby of Religion, pp. 148-243.

${ }^{100}$ J. L. Heiberg, Poetiske Skrifter, 10, pp. 163-324. Martensen's review, "Nye Digte af J.L. Heiberg”, appeared in Fædrelandet, vol. 2, no. 398 (January 10, 1841), cols. 3205-12; no. 399 (January 11, 1841), cols. 3213-20; and no. 400 (January 12, 841), cols. 3221-24. Heiberg's book of poems and Martensen's review have been discussed in George Pattison, Kierkegaard: The Aesthetic and the Religious, pp. 21-22, and Kierkegaard, Religion and the nineteenth-Century Culture of Crisis, pp. 99, 110-115; K. Brian Soderquist, The Isolated Self, pp. 12, 186-187; Robert Leslie Horn, Positivity and Dialectic, pp. 169-177; Jon Stewart, A History of Hegelianism in Golden Age Denmark, Tome II: The Martensen Period: 1837-1842, pp.508-545; István Czakó, "Heiberg and the Immortality Debate: A Historical Overview," Johan Ludvig Heiberg: Philosopher, Littérateur, Dramaturge, and Political Thinker, pp. 132-138; Carl Henrick Koch, "Aesthetics and Christianity in the Early Works of H. L. Martensen," Hans Lassen Martensen: Theologian, Philosopher and Social Critic," edited by Jon Stewart, Copenhagen: Museum Tusculanum Press / Søren Kierkegaard Research Centre, University of Copenhagen 2012, pp. 202-205, 208, 212-213; Jon Stewart, The Cultural Crisis of the Danish Golden Age: Heiberg, Martensen and Kierkegaard, pp. 117-143. 
the spirit of modernity which sits in judgment on those who would deny it. ${ }^{101}$ The primary vehicle of emancipation is apocalyptic poetry, which is now designated as that which allows one to gain a glimpse into the world beyond, so that it in addition portrays the resurrection of the present world for judgment. Thus the emphasis of the long review falls on Heiberg's "A Soul after Death: An Apocalyptic Comedy," which is generally acknowledged as a classic of Danish literature. The focus is on a single soul, whose destiny is not tragic, but comical. In Heiberg's comedy, it is the world of Copenhagen life in all its petty detail that has been resurrected for judgment. The result is a look at the kingdom of triviality.

Martensen proceeds to develop the theory behind "the metaphysics of triviality" presented by Heiberg in his poem. ${ }^{102}$ The kingdom of the bad or the insignificant or meaningless is distinguished from the kingdom of evil. ${ }^{103}$ He writes:

The bad [slette] is a more immediate and lower category than evil [Onde\}, for evil is the Idea's spiritual opposite and therefore contains a reflection of the Idea; the bad to the contrary is only its immediate, reflectionless contrast. Evil always has a certain inspiration, indeed sometimes even its peculiar inspiration; the bad indicates only the spiritual zero point, expresses not so much the spiritual opposite to the Idea, as the perfect interestlessness and indifferentness. Its kingdom is therefore that of triviality. The bad and the trivial are expressions for the same concept, only that the trivial designates more the phenomenon, the bad the essence. This kingdom is not far away from us. It is not merely limited to life's practical sphere, but also in the theoretical sphere, in science and art it has its wide-ranging provinces. ${ }^{104}$

The trivial is that which begins to become obsolete in the same moment it is born; when productions in science and art become obsolete over the course of time, then it is only because they originally contained a moment of triviality latent within them, the discovery of which resulted in boredom. ${ }^{105}$

${ }^{101}$ Martensen, "Nye Digte af J.L. Heiberg," col. 3205.

102 Martensen, "Nye Digte af J.L. Heiberg," col. 3208.

${ }^{103}$ Hegel, of course, had his category of the "bad infinity," and Heiberg, "A Few Words about the Infinite," Heiberg's Contingency Regarded from the Point of View of Logic and Other Texts, trans. by Jon Stewart, Copenhagen: Museum Tusculanum Press / Søren Kierkegaard Research Centre, University of Copenhagen 2008, p. 164, clarifies that thinking of infinity as a continuous progress to the beyond, be it in space, time, or idea, is a bad infinity that is a less than edifying notion.

${ }^{104}$ Martensen, "Nye Digte af J.L. Heiberg," col. 3207-8.

${ }^{105}$ Martensen, "Nye Digte af J.L. Heiberg," col. 3208. 
As the spirit contains the unity of the infinite and the finite, so does the spiritless always appear when these moments indifferently turn away from each other. One can therefore define the trivial as the absolutely undialectical, the tautological, that which only is itself but has lost the transition to its other. It is the flat and empty because in this is seen only an abstract, meaningless one, instead of the two-in-one which should be seen. ${ }^{106}$ Triviality, roughly the equivalent of Hegel's bad infinity, is the result of a similarity of vision:

Genuine science and poetry, just like faith, see all objects in a twofold way, see them simultaneously under the gestalt of eternity and temporality. This double view appears on the whole in everything that is called witty. The bad, flat view of the world, on the other hand, sees everything only in a single way. It is one-eyed and has no copula between the infinite and the finite, the supernatural and the natural, between thought and the empirical, a priori and a posteriori. When one of these moments arises within the horizon of triviality, the other lies outside of it. They are only separated, but never appear together. ${ }^{107}$

It is on account of this empty monistic view that the worldview of triviality denies the mystery in religion, the Concept in science, and the ideal in art. The true worldview, on the other hand, grants that an inexhaustible dialectic is at work everywhere revealing itself. When the manifestations of this dialectic become trivial, then the fault lies in the eye of the beholder, who is conceiving reality with a meaningless, tautological eye capable of seeing only factual, unproductive knowledge. ${ }^{108}$ The "bad" worldview follows the true one as the shadow follows the body, or the caricature the ideal. ${ }^{109}$ It is this contrast between monistic and idealistic worldviews which, in Martensen's mind, divides all literature and separates all authors. "Bad are all the practical thoughts that are not able to be realized, and bad is the actuality that does not bear the image of thought." 110 When triviality, which extends into the practical sphere by propounding an impersonal morality to match the spiritless thought-world, becomes all in all and forms an independent kingdom, then appears the shape or form of hell which Heiberg has envisioned in his apocalypse. The existence of trivial souls has only been an

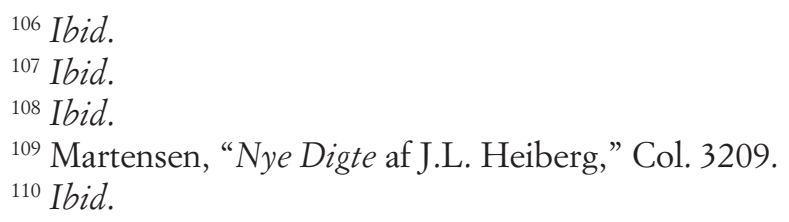


existence of illusory being, therefore they are excluded from the kingdom of heaven as well as the kingdom of evil, for the latter is reserved for those who have always strived, though in a false way, after spirit and personality. ${ }^{111}$

In the apocalyptic vision which Martensen portrays, the concepts of the comical and the cosmical are especially important. We recall that earlier in his "Fata Morgana" review, Martensen had developed the concept of the comical as being higher than the tragic. Here he again expounds on this theme. If the tragic depends on the ethical contrast between good and evil, the comical depends on the metaphysical contrast between the empirical existence of the spirit and its concept, between illusory being or appearance and essence. ${ }^{112}$ Dante's hell is a tragic vision; Heiberg's depiction of the kingdom of triviality is comical because in following the philosophical nature of Protestantism it cannot remain content with the concrete forms of actuality of the spirit (the collision of which gives rise to tragedy) but wants to grasp spirit in its pure metaphysical freedom whose aesthetic expression is the comical. ${ }^{113}$ Martensen contends that a Protestant divine comedy must incorporate the whole tragic side that Dante has emphasized, but in addition must integrate throughout the dialectic of the comical. This means that hell must be illuminated in a dual way, so that it can be seen as evil but also as the bad, so that light shines on hell from both the religious-ethical side but also from the metaphysical side. ${ }^{114}$ The Christian apocalypse thus includes the comical, through which the world in all its fullness is granted constitutive significance for the heavenly vision.

Inadequate in Martensen's eyes is that paradise which has been described by theologians and poets alike as being a place where one tautologically sings songs to God's honor, because it lacks content: here the blissful spirits find God but not the world, or at most only a world of cherubim and seraphim which is cleansed from all change. ${ }^{115}$ Martensen acknowledges that Christian doctrine has wanted to affirm that this world passes away, and that in this affirmation lies the ground for the world not being granted any actual eternity. ${ }^{116}$ But that does not prevent this world from being maintained in a phenomenal eternity. As surely as the comical has reality in the

${ }^{111}$ Ibid.

${ }^{112}$ Martensen, "Nye Digte af J.L. Heiberg," col. 3209-10. This is Martensen's distinction between essential and subjective freedom.

${ }^{113}$ Martensen, "Nye Digte af J.L. Heiberg," col. 3210.

${ }^{114}$ Ibid.

${ }^{115}$ Martensen, "Nye Digte af J.L. Heiberg," col. 3211.

${ }^{116} \mathrm{Ibid}$. 
apocalyptic vision, just as surely is this world in all its frailty assured of a phenomenal eternity: "The phenomenal eternity is only an eternity in image, in the mirror, against which the Christian eternity, as the personality's life in God, as the glory of creation beholds the freedom of the children of God, is the actual eternity"; this phenomenal eternity is found in art and reflective thought, but also "in all of life's immediate joys, in each of life's summer night's dreams, in love, in short, in every enjoyment which allows the human to forget that he or she is in time. ${ }^{117}$

The concept of the comical entails the exchange of transitory actuality for appearance, show, or illusory being, but it also involves a conservation of this:

The tragic has validity only so long as this world endures with its struggles and pains; the comical on the other hand outlives the world's destruction, will in spite of its destruction keep it and immortalize it - not in actuality, nor in abstract memory, but in appearance. In this form the entire secular world becomes preserved for an eternal joy of the spirit, which through this secures for itself consciousness of its own essentiality. In this way the world's vanity receives its necessary place in God's kingdom. ${ }^{118}$

It is for this reason that the details of life in Copenhagen have a place in an apocalyptic comedy. The comical entails the cosmical. ${ }^{119}$

"A Soul After Death" can also be considered in relation to what Martensen refers to as "the modern apokatastasis of all things." 120 Then the comical will clearly be seen to possess a greater dignity than the tragic, or rather, "the dialectic between the comical and the tragic will come to rest in the

117 Martensen, “Nye Digte af J.L. Heiberg," col. 3215.

${ }_{118}$ Martensen, "Nye Digte af J.L. Heiberg," col. 3211.

${ }^{119}$ Ibid. Martensen writes in col. 3210: "The comical is a category which also in heaven will have its validity. They will then as blessed spirits play with their temporal phenomena of consciousness: their empirical actuality with all its detail, with all its frailty and transitoriness they will take with them in heaven, because it must serve them as a poetic material through which spirit prepares itself for the enjoyment of its infinite freedom and blessedness. Their temporal, childish interest will then appear as accidents in the substance of blessedness." It should be kept in mind here, of course, that it is Hegelian metaphysics, and in particular Hegel's notion of Aufhebung, as not only an annulment but a preservation, that is informing this vision of the comical as including the cosmical.

${ }^{120}$ Martensen, "Nye Digte af J.L. Heiberg," col. 3212. Biblically, the term apokatastasis is used in Acts 3:21 in Peter's sermon, and theological, it is associated most closely with the Origen of Alexandria. 
bumoristic, as not merely a negative but a positive comical, the speculative comical, which is related to irony as profundity to acuteness":

The humoristic, which belongs exclusively to Christianity, contains all irony, the poetic justice over the fallen world, but in addition the fullness of love and reconciliation. It contains all the world's suffering overcome in a depth of richness of joy. Just because the humoristic view considers the whole world not merely through a moral but a metaphysical medium, it sees all oppositions as dialectical; the same principle of sinfulness which is in the evil person it also sees in those who are called good and pious, the same mark of finitude in the one who is called insignificant it also sees in the one who is called high and mighty; it is vanity all the same and for that reason it all the same still only belongs to this transitory world. But it loves the world in spite of its transitoriness, its wickedness and badness, and just as it allows all finitude without exception to be destroyed and annuls the difference between the great and small, so does it also save and restore the whole of finitude, the least with the greatest. ${ }^{121}$

Therefore, Martensen concludes that in a divine comedy which had the humoristic as its principle, God would not merely be represented as the righteous judge of the world, but as the absolute spirit, who views humans not merely through ethical but just as much through metaphysical categories, not merely through tragic but just as much through comical categories. ${ }^{122}$ And this absolute spirit, in addition, would be seen as restoring one and all to favor, because each is not merely sinful, but evil, culpable, and fallen, but also finite, bad, ridiculous, and belonging to a fallen world. ${ }^{123}$ As Soderquist notes: As the "negative comedy" of the egocentric ironic consciousness is supplanted by the "positive comedy" of the humoristic consciousness, the status of the world has been transfigured from a "hollow" other of the subject to an other now "reconciled' to the subject; such a "saved" world is the work of Cbristian humor. ${ }^{124}$

The natural reaction to this view of the judgment of God in terms of a divine comedy is to suggest that it surely takes seriously the role of divine grace, but does not do the same for human freedom. It is interesting that Martensen moves away from this position to a more agnostic one in developing his eschatology in his dogmatics. But here it should be remembered
${ }^{121}$ Ibid.
${ }^{122}$ Ibid.
${ }^{123}$ Ibid.
${ }^{124}$ Soderquist, The Isolated Self, p. 186. 
that Martensen recognizes Heiberg's poem as being a critique of Copenhagen culture and life. When the soul in the poem arrives in hell it has only arrived again in Copenhagen. ${ }^{125}$ Martensen suggests that those who complain about Heiberg's inclusion in his poem of many particulars of Copenhagen life, including particular people, have missed the point: that the particular here is only an accidental and disappearing moment in that irony which has a quite universal content. And it belongs to the style of Aristophanes, who along with St. Peter is a main character in the poetic drama, to be local. Other critics have been repulsed by Heiberg's obvious effort to make an ethical claim about the life in Copenhagen, for they are of the opinion that the comical is to be motiveless if the full hilarity and freedom is not to be squelched. But to this Martensen responds that if one wants to reject every personal motive as having any place in comedy, then one must condemn the whole Aristophanian type of comedy, and even a person like Socrates must then be abandoned. ${ }^{126}$

The soul in Heiberg's poem in one respect has suffered a most unfortunate fate and therefore can lead to some very serious reflections; and yet, on a closer look, it is comical:

Comical it is, namely, because "the soul" in all its adversity preserves its good humor and does not lose its calm equilibrium. It is so secure in the reality of its view of life that neither by St. Peter or Aristophanes can it be disoriented. Comical is this soul because it is so respectable and well-thought of, but does not notice that it always accomplishes the bad; because it is enthusiastic about the practical and real, but does not notice that it finally is only a bad idealist who has spun itself within a web of illusions; because it is indefatigably active and striving, but does not notice that it never starts, and if from time to time it notices this, it does nothing about it but maintains an unruffled harmony with itself. ${ }^{127}$

So this soul is not aware that it has entered hell. Only the external spectator knows this. The soul itself thinks it is now in eternity. Whether it will be able to be emancipated from this bad eternity or be doomed irrevocably to remain there, is a question the answer to which Martensen believes depends on whether or not this soul can turn itself around and this again depends on whether it can arrive at a true self-knowledge:

\footnotetext{
${ }^{125}$ Martensen, “Nye Digte af J.L. Heiberg,” col. 3217.

${ }^{126} \mathrm{Ibid}$.

${ }^{127}$ Ibid.
} 
Hence, if it can become comical not merely for others, but for itself, if it can arrive at a higher irony over both itself and over Mephistopheles, it will also be able to be emancipated. Its realistic inveteracy will then be dissolved and disappear in a humoristic aether, through which it will be advanced to a better blessedness. ${ }^{128}$

Martensen is willing to leave open whether this will happen with the soul in Heiberg's poem. But since the soul's fate is revealed for "the surviving," the hope is that by seeing themselves in a mirror, the people of Copenhagen will arrive at this self-knowledge and, finding themselves infinitely comical, be emancipated from their inveteracy:

For just as liberation from evil happens most precisely through tears, so does the liberation from the domination of triviality happen most precisely through laughter. And just as the sinner who is capable of shedding tears over herself by this shows that she is not absolutely evil but gives the good a power in itself, so is the one who is capable of finding her own triviality laughable not absolutely spiritless, as she by this goes beyond herself and abandons the bad. ${ }^{129}$

Consequently, if people are able to furnish evidence of a higher self-consciousness, then more cheerful prospects will be opened for them. Apocalyptic poetry brings the speculative Idea to the populous, but we can see from this that it obviously need not do so in an uncritical way. While it is possible to excuse the phenomenal in dwelling on the ideal and thus have a conservative political theory based on the Idea, one can also here recognize, even if Heiberg's focus is confined to the individual, the potential for an idealistic critical theory: in illuminating the true reality of a situation, the Idea renders judgment on the status quo.

Having summarized Martensen's explication of Heiberg's metaphysics of triviality, we must not leave unmentioned his striking comments on Heiberg's poems on the theme of "Protestantism in Nature." Martensen's religious confessionalism, or some would say his religious chauvinism, is evident here, and elsewhere as we have seen, in his claim that Christianity is the true religion and Protestantism is the true Christianity. ${ }^{130}$ The essence of Protestantism Martensen finds in the striving of freedom towards the ideal, in a continual transcending of immediate actuality. Therefore, he states

128 Ibid.

${ }^{129}$ Martensen, “Nye Digte af J.L. Heiberg,” col. 3218.

${ }^{130}$ Martensen, "Nye Digte af J.L. Heiberg," col. 3222. Elsewhere he goes on to claim Lutheranism as the true Protestantism. 
that this same Protestantism, which appears subjectively in the spirit, must be conferred on nature objectively insofar as it vaguely and unconsciously strives to be transformed from its immediate actuality into its ideal. ${ }^{131} \mathrm{We}$ have here, it seems, an expression of what Alfred North Whitehead will later call "the reformed subjectivist principle." Nature protests. It protests even against all naturalism, Martensen claims, both in an aesthetic and a religious respect. ${ }^{132}$ This knowledge has arisen for Heiberg who now can dedicate himself entirely to the service of Protestantism, since not merely the spirit but nature itself has protested. ${ }^{133}$ Heiberg's poem has contributed not a little to bringing Protestantism's pneumatic or spiritual reflection on nature to consciousness:

This reflection on nature in the poet shall not merely appear in the religious intuition of nature, but shall appear just as much in all spheres of poetry in a pneumatic treatment of nature. Just as nature with a quiet voice expresses its longing for the magnificence of the world to come, so does it already now demand to be explained in the poet's spirit. ${ }^{134}$

The true writer of poetry will not appropriate nature in its raw, unredeemed state, nor use it in the service of corruption. Rather, in offering a pneumatic treatment of nature, the genuine poet will come especially to make use of picture language. In fact, Martensen believes one can draw a parallel between the way poets use images together with their placement of the poetic moment of nature to the Idea and the way various Christian confessions treat picture-language in relation to the Eucharist, e.g., the Catholic transubstantiation, the Reformed allegory, the Lutheran spiritual presence. ${ }^{135}$ Just as poetry only finds its true explanation with religion, so will a deeper aesthetic consideration on many occasions be able to shed a stimulating light on theology. ${ }^{136}$

This claim for the complementarity between aesthetic theory and theology has been exemplified in Martensen's aesthetic construals. Those aesthetic construals have often been influenced by his theology and in some instances they might have influenced his theology. He did not keep the issue of construing aesthetics near the top of his list after 1841. He headed more

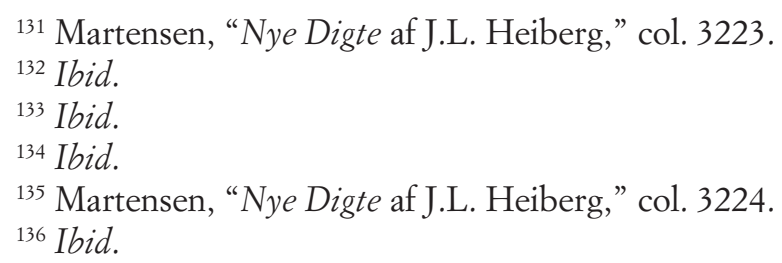


in the interest of dogmatics. However, it did not find the need to criticize or retract the above-recounted construals at a later time.

\section{$V I$}

The discussion could be brought to a close right here. But that would be to leave the construal that has been offered largely in the past. We know, though, that a construal or interpretation of some import is going to have more value if the consideration is brought into relation with the present. We began our deliberations with a reminder from Robert Pippin that since Kant there has been an acknowledgment by many of a distinctive aesthetic mode of intelligibility. Heiberg and Martensen surely affirmed such a mode, and their deliberations on aesthetics resulted in some interesting insights. I believe that in traveling our narrative journey we have encountered some thoughts that are worth lifting up in order to point out their possible relevance to the contemporary situation. My perspective in identifying some of these pertinent matters for helping guide us through troubling times is shaped by the fact that, like Martensen, I operate as a theologian who desires to affirm significant experiences of meaning wherever those might be taking place within the culture.

A first point is that Heiberg and Martensen alike are open to appreciating meaning-making activities in whichever sphere or region of culture it might be occurring. In the instances considered here this was primarily in the context of the dramatic theater, but the contexts could be multiplied to include film, TV, dance, sports, and many other areas in which people are experiencing life-enhancing and sometimes life-changing encounters with profound stories, images, ideas, and values that might be cultural activities of a secular world but that nonetheless possess a potent religious dimension. These experiences are no less ambiguous than are more traditional religious experiences, but the point is that they are conjuring up greater awareness of what is most important in life, and therefore they are worthy of being endorsed and thought about in theological ways.

Second, the appearance/essence distinction is a relevant one to bring to bear on our situation or any situation for that matter. That is why it has been such a powerful tool in most religions. The twist here has been to emphasize harnessing this reflection to serve the heightening of consciousness concerning human freedom, that the essential matter is to own the fact of one's 
freedom and to take responsibility for how one uses one's freedom to give shape to one's life. This is easier said than done because life's appearances are continually in our face vying for our attention. Some of those appearances are glittering and glowing and alluring, so that it is easy to get caught up in them. Cutting through them to get to the essential core of the matter can be done, but it seems that many remain very content in a superficial life of becoming very comfortable in their cozy confines of a rapprochement with appearances. To some degree or other all of us succumb to this temptation to live a hell of a life, as Heiberg and Martensen would characterize it, but at the same time many of us realize the need to fight against that temptationin striving to actualize the ideal.

Closely related to capitulating to appearance is the third issue of the triviality that results from such capitulation. The metaphysics of triviality that Martensen identifies is a form of nihilism that underscores life's nothingness and vacuity. The trivial is shorn of its dialectical connections. Preoccupied by trivial concerns and tasks, one loses an appreciation for truth, beauty, and goodness. Becoming caught up in the trivial leaves one without a sense of purpose and alienated from existence. Boredom becomes the order of the day and doubt concerning this particular and that eventually leaves one in despair or without a basis for hope. If an awareness of eternity envelops one's existence and can bring unity to the personal narrative that one is playing out, being lost in triviality is the condition of not having such an awareness. Of course, without an awareness of eternity, one can also be blithely content with one's trivial life since it's all one knows. Some contemporary cultural manifestations of meaning give expressions to triviality, but some of them also help to jolt people out of living complacently in that sort of delimited world.

Becoming liberated from the kingdom of triviality, point four, is not likely to begin to take place until one's entanglement becomes disrupted by how one views the world. If one's viewpoint is monistic, then there is little chance of escaping the clutches of triviality's entanglement. For such one-eyed seeing tends only to the flat, surface-aspects of reality that don't transcend the uni-dimensionality of the trivial that proclaims there is nothing in life to become excited about. True infinity, according to Hegel's view, is to be found in the dialectical relation between the infinite and the finite, through seeing these two in one. Two-eyed seeing, then, does not limit its attention to the flat, surface-character of temporal reality but takes into account as well its eternal dimension, its episodes of higher and deeper 
meaning that open one's experience to a much bigger reality that is bursting forth with significant connections and creative occurrences. Becoming accustomed to two-eyed seeing is to be reborn into a bright world full of adventure, discovery, mystery, meaning, and serendipity. Obviously, secular forms of religion serve a major role in sponsoring the need for operating beyond the monistic mindset.

Living out of a two-eyed seeing of the world makes possible the rich stances of irony, the comical, and the humorous, a fifth point of relevance for negotiating life in our contemporary world. Irony represents one form of two-eyed viewing of reality. Romanticism's infatuation with irony in many instances fell short of being fully edifying because it did not have adequate limits to keep its egotism under control so that it could be properly freed from the finite world. ${ }^{137}$ Irony gains distance from the world by breaking with the immediacy of experience. It provides an independent perspective on the world's follies, but the ironic judge of the world excludes himself from judgment and rather stands apart in superiority over the illusory world of everyday consciousness that soon is viewed through nihilistic eyes. Comedy on the other hand brings a similar distantiation from the world but with a more extensive judgment now including the beholder's foolishness too within its grasp. Comedy's sub-category of humor, for Martensen a Christian category, entails the humble adopting of a metaphysical view that regards finite reality as not just foolish but as fallen, but that reestablishes a connection to the infinite and affirms a reconciliation between the infinite and the finite. All three of these tools can contribute to enabling us to cope in positive ways with the finite world that is the only one we have. ${ }^{138}$

Another implicit insight informed the work of Heiberg and Martensen on aesthetics. That sixth point is that it matters where the public comes down in its receptivity or lack thereof of the creative work being presented. That was the case in the theater of Copenhagen in Golden Age Denmark and it is the case no less in the churches of Christianity in the U.S. of A. If Christianity has lost its audience because many younger as well as some older people can no longer readily relate to the beliefs, rituals, and ways of operating of Christian church traditions, then it seems that thoughtful lead-

${ }^{137}$ Jon Stewart has made a convincing case that Kierkegaard's solution to this situation, "controlled irony," is comparable to the "higher irony" that Martensen here suggests as the needed remedy. See Stewart's Chapter 9 on "Kierkegaard's Enigmatic Reference to Martensen in The Concept of Irony," in The Cultural Crisis of the Danish Golden Age, pp. 215-231.

${ }^{138}$ For a thorough treatment of these three themes, see Soderquist's The Isolated Self. 
ers should be making an effort to open up different ways of communicating with these people, ways that go to where these people are rather than expecting them to make their way into the churches, ways that listen intently to find out about the manner in which they are experiencing meaning in their lives. Such a process of genuine seeking could lead to a much-needed self-criticism of the church that could transform how it carries out its work.

A seventh matter that comes to the fore in the above narrative is that of courage. This applies to the creative work being carried out at this time by both Heiberg and Martensen, but I'm thinking here more of the latter figure. The young fledgling professor still wet behind the ears steps into the role of public theologian that places him on very much uncharted terrain. Embedded in this context, he is called to engage in working out issues that have arisen by formulating central ideas for a theology of culture addressing the situation. The thirty-year-old demonstrates a bold self-confidence as he marches ahead with his creative construing in relation to the cultured elites of Copenhagen society, but shining through his contributions is also an element of courage that might inspire those faced with a similar challenge today.

Closely connected to the previous point is the eighth observation that even though one is engaged as a theologian in arenas somewhat far removed from the more traditional domains and loci of theological reflection, it is possible to maintain one's integrity as a person of faithful commitment. All good theologians recognize the challenges involved in their creative task of bringing into a living synthesis the deliverances of a religious tradition and the thought-world of the contemporary cultural context. But the challenges are intensified when the work engages one in developing a theology of culture. Martensen exemplifies how this can be accomplished without losing one's religious identity to the gusty winds of change introduced by a newly emerging spirit of the times.

The ninth and final point of relevance concerns the central antagonist in Heiberg's Fata Morgana, the Queen of Illusion herself. The fairy Fata Morgana represents the power of illusion and she possesses great power to lead people into life's mere appearances and away from essential truths. Resulting is a confusing relativism that cannot rely on the reality of truth. The way to defeat the mistress of illusion is not to rest content in the world of shadowy appearances she presents but to move instead into the deeper truths of life such as beauty, justice, love, and goodness. This Morgana figure is highly relevant to life in 2017 because we are dealing with a presiden- 
tial figure who is the King of Illusion. With Donald J. Trump's strategy of employing "fake news" himself by way of a continual barrage of tweets and labeling the truths of genuine journalism as "fake news" in order to divert attention away from the important matters at hand, he is obfuscating previously agreed-upon principles of reality and introducing a relativism of truth that debilitates communication and confuses people who hold too dear the authority of his office. Not many times in American civic life has there been such a need to be able to get behind appearances to the truth of the matter at hand and to ferret out what is actually going on. Much can be learned from Heiberg's Fata Morgana and from Martensen's construal of it for assisting us to deal as constructively as possible with the desperate situation of living together in the surreal world of Trump.

\section{Bibliography}

Bosanquet, Bernard, A History of Aesthetic, Cleveland: The World Publishing Company 1932, $3^{\text {rd }}$ edition, 1961.

Czakó, István, "Heiberg and the Immortality Debate: A Historical Overview," Johan Ludvig Heiberg: Philosopher, Littérateur, Dramaturge, and Political Thinker, ed. by Jon Stewart, Copenhagen: Museum Tusculanum Press / Søren Kierkegaard Research Centre, University of Copenhagen 2008, (Danish Golden Age Studies, vol. 5), pp. 132-138.

Hegel, F. W., Hegel's Aesthetics: Lectures on Fine Art, trans. by T. M. Knox, 2 vols. Oxford: Clarendon Press 1975.

Heiberg, Johan Ludvig, "Et Par Ord om det Uendelige," in Kjøbenhavns flyvende Post, no. 100, December 15, 1828, [pp. 413-414]. (In English as "A Few Words about the Infinite," in Heiberg's Contingency Regarded from the Point of View of Logic and Other Texts, ed. and trans. by Jon Stewart, Copenhagen: Museum Tusculanum 2008 (Texts from Golden Age Denmark, vol. 4), pp. 163-166.

Fata Morgana, Eventyr-Comedie, Copenhagen: J.H. Schubothes Boghandling 1838. (Reprinted in Poetiske Skrifter, vols. 1-11, Copenhagen: C.A. Reitzel 1862, vol. 2, pp. 93-226.).

- Nye Digte, Copenhagen: C.A. Reitzel Publisher 1841. Reprinted in Poetiske Skrifter, vols. 1-8, Copenhagen: J.H. Schubothes Boghandling 1848-49, vol. 7, pp. 191-203, vol. 2, pp. 313-379; vol. 7, pp. 125-168; vol. 7, pp. 204-207 (reprinted as individual poems). Poetiske Skrifter, vols. 1-11, Copenhagen: C.A. Reitzel 1862, vol. 10, pp.163-324. 
Horn, Robert Leslie, Positivity and Dialectic: A Study of the Theological Method of Hans Lassen Martensen, Copenhagen: Søren Kierkegaard Research Centre / C. A. Reitzel's Publishers 2007 (Danish Golden Age Studies, vol. 2).

Koch, Carl Henrik, "Aesthetics and Christianity in the Early Works of H. L. Martensen," Hans Lassen Martensen: Theologian, Philosopher and Social Critic," ed. by Jon Stewart, Copenhagen: Museum Tusculanum Press / Søren Kierkegaard Research Centre, University of Copenhagen 2012.

_ "Heiberg's 'Hegelian' Solution to the Free Will Problem," Johan Ludvig Heiberg: Philosopher, Littérateur, Dramaturge, and Political Thinker, ed. by Jon Stewart (Copenhagen: Museum Tusculanum Press / Søren Kierkegaard Research Centre, University of Copenhagen 2008), pp. 5-36.

Kramer, Nathaniel and Matthew, Ancell, "Heiberg, The Golden Age, and the Danish Afterlives of Pedro Calderón de la Barca," Johan Ludvig Heiberg: Philosopher, Littérateur, Dramaturge, and Political Thinker, ed. by Jon Stewart, Copenhagen: Museum Tusculanum Press / Søren Kierkegaard Research Centre, University of Copenhagen 2008, (Danish Golden Age Studies, vol. 5), pp. 327-356.

Martensen, Hans Lassen, "E. G. Kolthoff, Apocalyps Joanni Apostolo Vindicata," in Maanedsskrift for Litteratur, vol. 12, 1834, pp. 1-31.

Johannes M.......n, Ueber Lenau's Faust, Stuttgart: Verlag der J.G. Cotta'schen Buchhandlung 1836.

"Indledningsforedrag til det I November 1834 begyndte logiske Cursus paa den kongelige militaire Høiskole. Af J.L. Heiberg, Lærer I Logik og Æsthetik ved den kgl. Militaire Høiskole," in Maanedsskrift for Litteratur, vol. 16, 1936, pp. 515 528. English translation: "Review of the Introductory Lecture to the Logic Course," trans. by Jon Stewart, in Heiberg's Introductory Lecture to the Logic Course and Other Texts, ed. and trans. by Jon Stewart, Copenhagen: C. A. Reitzel / Søren Kierkegaard Research Centre 2007, pp. 73-86.

"Betragtninger over Ideen af Faust. Med Hensyn paa Lenaus Faust," in Perseus, Journal for den speculative Idea, no. 1, 1837, pp. 91-164. The essay was republished in Mindre Skrifter og Taler by Biskop Martensen, Udgivne med en Oversigt over hans Forfattervirksomhed af Julius Martensen. Copenhagen: Gyldendal 1885, pp. 27-88.

De autonomia conscientiae sui bumane, in theologiam dogmaticam nostri temporis introducta, Copenhagen: Danish translation: Den menneskelige Selvbevidstheds Autonomie, trans. by L.V. Petersen, Copenhagen: 1841. (English translation: The Autonomy of Human Self-Consciousness in Modern Dogmatic Theology in Between Hegel and Kierkegaard: Hans L. Martensen's Philosophy of Religion, trans. by Curtis L. Thompson and David J. Kangas, Atlanta Scholars Press 1997, pp. 73-147.) 
_- Fata Morgana, Eventyr-Comedie af Johan Ludvig Heiberg. 1838. Copenhagen: Schubothes Boghandling 1838," in Maanedsskrift for Litteratur, vol. 19, 1838, p. 361-397.

"Rationalisme, Supranaturalisme og principium exclusi medii i Anledning af. H. Biskop Mynsters afhandling herom i dette Tidsskrifts forrige Hefte," in Tidsskrift for Litteratur og Kritik, vol. I, 1839, pp. 456-473.

- Meister Eckart. Et Bidrag til at oplyse Middelalderens Mystik. Copenhagen 1840. (English translation: Meister Eckhart: A Study in Speculative Theology, in Between Hegel and Kierkegaard: Hans L. Martensen's Philosophy of Religion, trans. by Curtis L. Thompson and David J Kangas, Atlanta Scholars Press 1997, pp. 140243.

“Nye Digte af J.L. Heiberg," in Fædrelandet, vol. 2, no. 398 (January 10, 1841), cols. 3205-12; no. 399 (January 11, 1841), cols. 3213-20; and no. 400 (January 12,841$)$, cols. 3221-24.

— Af mit Levnet. Meddelser, vols. 1-3, Copenhagen: Gyldendal 1882-83.

Martensen, Julius, Mindre Skrifter og Taler by Biskop Martensen, Udgivne med en Oversigt over hans Forfattervirksomhed af Julius Martensen, Copenhagen: Gyldendal 1885.

Olesen, Tonny Aagaard, "Heiberg's Initial Approach: The Prelude to His Critical Breakthrough," Johan Ludvig Heiberg: Philosopher, Littérateur, Dramaturge, and Political Thinker, ed. by Jon Stewart, Copenhagen: Museum Tusculanum Press / Søren Kierkegaard Research Centre, University of Copenhagen 2008 (Danish Golden Age Studies, vol. 5), pp. 211-245.

Pattison, George, Kierkegaard: The Aesthetic and the Religious, New York: St. Martin's Press 1992.

Kierkegaard, Religion and the nineteenth-Century Culture of Crisis, Cambridge: Cambridge University Press 2002.

Pippin, Robert B., After the Beautiful: Hegel and the Philosophy of Pictorial Modernism. Chicago: The University of Chicago Press 2014.

Soderquist, K. Brian, The Isolated Self: Truth and Untruth in Søren Kierkegaard's On the Concept of Irony, Copenhagen: Søren Kierkegaard Research Centre / C. A. Reitzel 2007 (Danish Golden Age Studies, vol. 1).

Stewart, Jon, A History of Hegelianism in Golden Age Denmark, Tome I: The Heiberg Period: 1824-1836, Tome II: The Martensen Period 1837-1842, Copenhagen: Søren Kierkegaard Research Centre / C. A. Reitzel's Publishers 2007. 
- The Cultural Crisis of the Danish Golden Age: Heiberg, Martensen and Kierkegaard, Copenhagen: Museum Tusculanum Press / Søren Kierkegaard Research Centre 2015.

Søren Kierkegaard: Subjectivity, Irony, and the Crisis of Modernity, Oxford: Oxford University Press 2015.

Thompson, Curtis L., Following the Cultured Public's Chosen One: Why Martensen Mattered to Kierkegaard, Copenhagen: Museum Tusculanum Press / Søren Kierkegaard Research Center, 2008 (Danish Golden Age Studies, vol. 4). 